\title{
SYSTEM APPROCHES
}

DOI: 10.1556/Novenyterm.59.2010.Suppl.6 


\title{
AGRO-ECOSYSTEM PRODUCTIVITY AND RESILENCE IN ENVIRONMENTAL CONDITIONS OF THE SOUTHERN PANNONIAN BASIN
}

\author{
Dragisa MILOSEV ${ }^{1}$ - Srdjan SEREMESIC ${ }^{1}$ - Ivica DJALOVIC ${ }^{2}-$ Rudolf KASTORI $^{1}$ \\ - Milan JOCKOVIC ${ }^{2}$ \\ ${ }^{1}$ Department of Field and Vegetable Crops, Faculty of Agriculture, University of Novi Sad, Sq. Dositeja \\ obradovica 8, 21000 Novi Sad, Serbia, e-mail: mildr@polj.uns.ac.rs \\ ${ }^{2}$ Institute of Field and Vegetable Crops Novi Sad, 21000 Novi Sad, Maksima Gorkog 32, Serbia
}

\begin{abstract}
The aim of this study was to determine status and bearing capacity of the cropping systems for accomplishing the economically viable yields of winter wheat and maize. The data were obtained from the long-term experiment at the Rimski Sancevi experimental station. Observed yield were compared with the initial yield of the agro-ecological area, found before the experimental set up. Our result indicates that the investigated treatments have lost inherent productivity, irrespective to the cropping management applied. However, properly managed agro-ecosystems were capable to resist the pressure of production demand and responded with resilience to applied cropping technology over the years. Consequently, it was found that yield decline resulted from unfavorable climate condition, and fertilization had the crucial effects in yield preservation. At the end of the investigated period three-year rotation had highest utilization of the inherent agro-ecological yield potential with $152 \%$ for wheat and $471 \%$ for maize.
\end{abstract}

Keywords: agro-ecosystem performance, yield, winter wheat, maize

\section{Introduction}

Concerns over the long-term sustainable development of the agro-ecosystem resulted in a range of interpretation concepts for supportive biophysical resources, agrobiological and agrotechnical management maintenance. Fundamentally, achieving the resilience in agro-ecosystem under the mounting pressure of human population growth would require enhanced agricultural productive capacity while its resource base remains conserved. Likewise, Swift (1994), resilience defined as capacity of system to return to an equilibrium following the displacement in response to perturbation. Further on, evaluation of agro-ecosystem performance in the crop production has generated a range of experimental and theoretical methodologies (Berzsenyi, 2009). Even though, there is no universal indicator of change either in the state of environmental resources used or affected by agriculture, or in farming activities. However, simple analyze of the crop yields enables access to temporal and spatial development of the agro-ecosystem. Explanation of yield changes, however, must encompass an estimation of the initial productivity that involves inherent environmental conditions and tillage operations. The assessment of the contribution of various measures to yield formation of winter wheat and maize on chernozem soil has indicated that fertilization might be the most important practice in yield improvement. Subsequently, Milošev (2000) also confirmed effects of judicious fertilizers application on winter wheat yield of the Southern Pannonian basin. Similar result was presented in Kismányoky (2009) for Western Transdanubian brown forest soil in Hungary, and Chloupek et al. (2004) for Czech Republic.

The aim of this study was to determine status and bearing capacity of cropping systems for accomplishing the economically viable yields of winter wheat and maize. 


\section{Materials and methods}

The study was performed on a long-term experiment (LTE) carried out at the Rimski Šančevi Experimental Field of the Institute of Field and Vegetable Crops in Novi Sad (N 45 $19^{\circ}$, E $\left.19^{\circ} 50^{\circ}\right)$. The LTE was established on a chernozem soil. The study treatments were: a fertilized maize (MOM) and wheat monoculture (MOW); a 2-year crop rotation (maize-wheat) (MWF); a 3-year crop rotation (maize-soybean-wheat) (MSWF); a unfertilized 2-year crop rotation (maize-wheat) (MW); a unfertilized 3-year crop rotation (maize-soybean-wheat) (MSW) and a 12-year crop rotation (maize-wheatsugar beet-soybean) (MWSbSF). The treatments are regularly fertilized with mineral $\mathrm{N}$ fertilizers at $120 \mathrm{~kg} \mathrm{ha}^{-1}$ rate for maize and sugar beet, $100 \mathrm{~kg} \mathrm{ha}^{-1} \mathrm{~N}$ for winter wheat, and no fertilizers for soybean have been used. $\mathrm{P}$ or $\mathrm{K}$ and barnyard manure have been applied until 1986, later only mineral $\mathrm{N}$ was used due to high supply of these nutrients in soil (Milošev, 2000). The prevailing climate in the investigated area is continental, with an average annual precipitation of $611 \mathrm{~mm}$, and annual temperature $11,1^{\circ} \mathrm{C}$. The utilization of agro-ecological potential was calculated on the basis of the observed inherent yield of $995 \mathrm{~kg} \mathrm{ha}^{-1}$ for winter wheat and $2912 \mathrm{~kg} \mathrm{ha}^{-1}$ for maize (Stojkovic, 1972). The data were evaluated by least significant difference $\left(\mathrm{LSD}_{0.05}\right)$ test.

\section{Results and discussion}

Obtain results showed that the fertilized treatments of winter wheat (WMF, WMSF and WMSbSF) were higher in average yield (1970-2009) compared with the initial 5-years average (Figure 1 and 2). On contrary, MOW and the unfertilized treatments were lower in average yields after 40 years of the experimental running than the observed yield at the establishment of the trial (Seremesic et al., 2008). MSWF, MWSbSF and MWF effectively utilized the agroecological resources for accomplishment of higher yield, respectively, whereas the unfertilized treatment achieved yield comparable with the inherent yield of the investigated area presented in Stojkovic (1972). Observed yields from the unfertilized plots represent an initial yield potential of the agroecosystem after 60 years of continuous cropping. Yield variation was most pronounced in the MOW. Yields of maize decreased in all cropping systems accept for MWF. This could be explained with the revision of cropping technology and deterioration of the climatic condition in 1990-2005 when maize yield significantly declined (Figure 1 and 3).
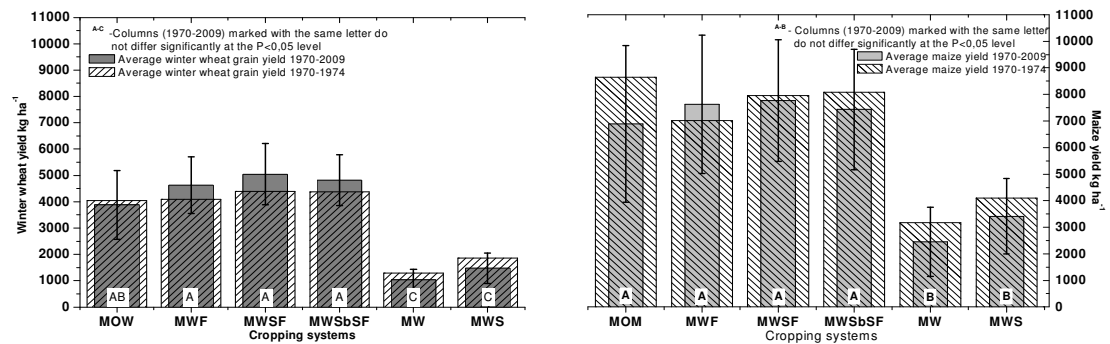

Figure 1. Average yield of winter wheat and maize at the LTE. (MOW-fertilized winter wheat monoculture; MOM-fertilized maize monoculture; WMF-fertilized two-year crop rotation; WSMF-fertilized three-year crop rotation; MWSbSF-fertilized twelve-years crop rotation; WM - Unfertilized two-year crop rotation; WSM - Unfertilized three-year crop rotation) 
Maize grown in the fertilized plots had responded better on favorable climatic conditions that resulted in higher variability of the fertilized treatments (Pepó, 2009; Huzsvay and Nagy 2005). Grain yield at MW was lower for $465 \mathrm{~kg} \mathrm{ha}^{-1}$ compared with the inherent yield of the area, and MWS was higher for $506 \mathrm{~kg} \mathrm{ha}^{-1}$ (Figure 2). Statistically significant difference in yield was found among fertilized and unfertilized treatments.

Generally, winter wheat yield of a different cropping systems in the LTE had a descending trend over a extended period of the time. The fertilized treatments was characterized with usage of $100-250 \%$ of the observed agroecological resources estimated before 1970. Climatic condition coused a major variation of yield, and in the fertilized treatments minimised efficient utilization of inherent yield potential. Additionally, management practices were not adjusted to the alteration in soil-water regime, once global warming was observed (Birkas, 2009). At the end of the investigated period MWSF was found to be most efficient in utilization of availible agroecological resources (152\%), whereas the WM (-25\%) and WMS (15\%) showed lower or similar yield compared with the inherent yield potential, respectively. Wheat monoculture was the most sensitive cropping strategy, and it should be avoided.

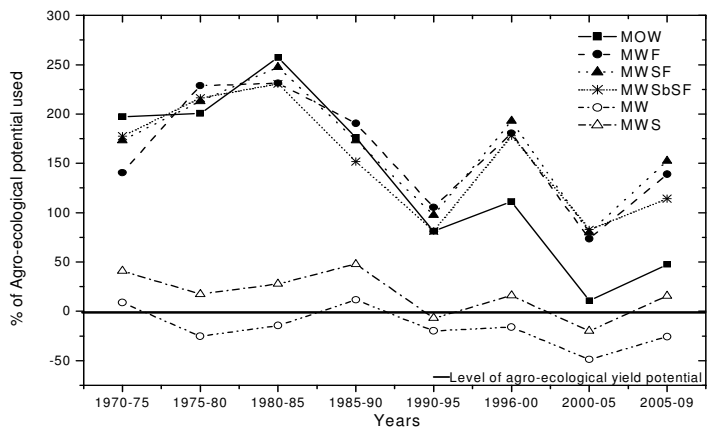

Figure 2. Utilization of inherent agro-ecological yield potential of winter wheat cropping systems

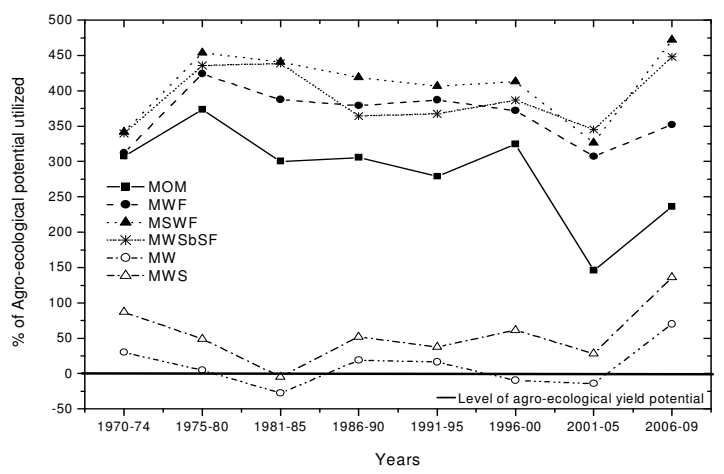

Figure 3. Utilization of inherent agro-ecological yield potential of maize cropping systems

591 DOI: 10.1556/Novenyterm.59.2010.Suppl.6 
Maize compared with winter wheat cropping showed higher usage of inherent agroecological resources (300-450\%) after the experimental arrangement (Figure 3). However, in the following period decreaseing yield trend was also observed, although last decade yield improvement was observed. This could be explained with the higher maize tolerance to effects of global warming (Kucharik and Serbin, 2008). Similar pattern of yield change was found in WMSF, WMF and WMSbSF, simultaneously maize monoculture yield potential diminish. Maize yield in the MW corresponded with inherent yield, whereas WMS yield was 50-100\% higher in the last decade.

\section{Conclusions}

Yields in the LTE had a decreasing trend except for maize in the last decade. Winter wheat showed insufficient ability for utilization of inherent agroecological resources compared with maize. Properly managed treatments were capable to resist the pressure and responded with resilience to climatic conditions and management technology. MWSF was higher in utilization of the inherent agro-ecological yield potential with $152 \%$ for wheat and $471 \%$ for maize. Obtain yield in the unfertilized treatment corresponded with the observed inherent yield of the agro-ecosystem. Resilience could be achieved only with the proper agronomic practices, among them fertilization could play a major role.

\section{Acknowledgements}

This study is part of the TR20082 project financially supported by the Ministry of Science of the Republic of Serbia.

\section{References}

Berzsenyi, Z.: 2009. New challenges and approaches for crop production research. Növénytermelés, 58:1. 7791.

Birkás, M.: 2009. Classic cultivation requirement and the need of reducing climatic damage. Növénytermelés, 58:2. 123-134.

Chloupek, O - Hrstkova, P - Schweigert, P.: 2004. Yield and its stability, crop diversity, adaptability and response to climate change, weather and fertilization over 75 years in the Czech Republic in comparison to some European countries. Field Crops Research 85: 167-190.

Huzsvay, L. - Nagy, J.: 2005. Effects of weather on maize yield and the efficiency of fertilization. Acta Agronomica Hungarica, 53: 31-39.

Kismányoky, T.: 2009. Examination of NPK fertilization and organic manuring of winter wheat in long-term experiment and cereal crop rotation. Növénytermelés, 58: 2. 59-73.

Kucharik, C.J. - Serbin, S,P.: 2008. Impacts of recent climate change on Wisconsin corn and soybean yield trends. Environmental research letters, 3: 034003 .

Milošev, D.: 2000. Selection of cropping system in winter wheat production. Anderejević Legacy, Beograd, 1166.

Pepó, P. 2009: Interactive effects of different crop years and agrotechnical factors on the yield of winter wheat (Triticum aestivum L.). Növénytermelés, 58:2. 107-122.

Seremesic, S. - Djuric, V. - Milosev, D. - Jacimovic, G.: 2008. The effects of crop rotation and nitrogen on grain yield and protein content of winter wheat. Cereal Research Communication, 36: 691-695.

Stojković, L.: 1972. Aspects of organic matter prodaction of field crops. Matica Srpska Proceedings for Natural Sciences, 41: 5-18.

Swift, M. J.: 1994. Maintaining the biological status of soil: a key to sustainable land management? In. Greenland, D. J. and Szabolocz, I. (ed.), Soil resilience and Sustainable Land Use. CAB International. Wallingford, 235-247. 


\title{
AIRBORNE HYPERSPECTRAL IMAGING FOR DATA COLLECTION FOR RESILIENT AGRO-ECOSYSTEMS
}

\author{
Gábor MILICS ${ }^{l}$ - István VIRÁG ${ }^{1}$ - Mohamed FAROUK Mohamed Ahmed ${ }^{2}$ - \\ Péter BURAI ${ }^{3}$ - Csaba LÉNÁRT ${ }^{3}$ \\ ${ }^{1}$ Institute of Biosystems Engineering, Faculty of Agricultural and Food Sciences, University of West \\ Hungary, H-9200 Mosonmagyaróvár Vár 2. Hungary, milics@mtk.nyme.hu \\ 2 Environmental Studies and Research Institute, Minufiya University, 32897, Sadat City, Egypt \\ ${ }^{3}$ Institute of Agroinformatics and Rural Development, Faculty of Agriculture, Károly Róbert College, H- \\ 3200, Gyöngyös, Mátrai u. 36., Hungary
}

\begin{abstract}
Agro-ecosystems are artificial systems that can tolerate disturbance up to a certain level. In order to find the threshold limits from what a disturbed agro-ecosystem can recover, different measurement techniques has to be applied. In plant production one of the most promising techniques is airborne hyperspectral imaging (AISA DUAL system). With this special remote sensing instrument data collection in the visible and near infrared spectra is carried out in order to determine different attributes of the Earth surface, in this case an experimental research field. By hyperspectral imaging various characteristics of plants (e.g. moisture content, protein content) can be measured during vegetation period. After harvest, in bare surface, soil parameters can be investigated. In present study an agricultural field is examined which is cultivated by means of precision agriculture technology. Quality and quantity parameters of winter wheat was measured by various online and offline sensors during harvest as well as by hyperspectral airborne imaging system prior to harvest. Data was compared by means of GIS softwares. After harvest, soil characteristics were measured and compared with a hyperspectral image in order to evaluate the applicability of the hyperspectral imaging system for different monitoring tasks in measurements in resilient agro-ecosystems.
\end{abstract}

Keywords: hyperspectral imaging, plant characteristics, soil properties

\section{Introduction}

Airborne hyperspectral imaging is a promising tool for many different land cover analysis applications. The very first time hyperspectral imaging was applied in Hungary on commercial base is dated to 2002. At that year various possible applications were investigated, such as determination of different forest types (Hargitai et al., 2006), investigation of plants under stress in towns (Jung, 2005). Hyperspectral imaging was evaluated from the point of view of ragweed detection (Kardeván et al., 2004) or soil protection (Pechmann et al., 2004). Tamás et al. (2005) reported the possible determination of non-vegetated areas by hyperspectral imaging using Normalized Differential Vegetation Index (NDVI). From agricultural point of view Papp and Fenyvesi (2007) published a summarizing article. Based on earlier experiments, measurements were carried out with different aims. Technical background of the measurements are reported by Deákvári et al. (2008). Application of hyperspectral imaging for precision farming as a resilient agro-ecosystem is reported in several earlier publications (Milics and Neményi 2007, Milics et al., 2008a; Milics et al., 2008b). At this stage field measurements are mandatory for data evaluation. Yield and grain quality measurement techniques are published for example by Neményi and Milics (2007), soil field measurements by Nagy et al., (2008) and Neményi et al., 2008. Estimation of soil moisture with areal images and hyperspectral data was reported by Lihua et al. (2005) with the correlation coefficient of 0.884 at the wavelength of $1000 \mathrm{~nm}$. Similar correlation was published by Sanchez (2003) at wavelength of 966 and $937 \mathrm{~nm}$. 


\section{Materials and methods}

In the experimental field cultivated by precision agriculture management technology since 2001 by University of West Hungary, all necessary research can be carried out in order to investigate the possible applications of the most up-to-date technology. The field is located near Mosonmagyaróvár, Hungary. For the airborne measurements AISA DUAL hyperspectral instrument was used, which is able to collect information in more than 350 different wavelengths between 400 and $2450 \mathrm{~nm}$. Aerial pictures were taken in two different times: one prior to harvest (2009.07.28) when the aim was investigation of winter wheat quality and quantity characteristics and one after harvest and disking (2009.09.10) when the aim was to investigate correlation between bare soil surface reflectance and different soil characteristics.

For the earlier image, data collection on the field was carried out by different sensors, such as Agrocom Yield Monitoring System for yield and grain moisture content measurements and Zeltex On-Combine Grain Analyzer for protein content measurements.

For the later image, different soil physical and chemical parameter collection was carried out, such as soil moisture measurements and soil sampling for chemical analysis. Soil moisture measurement was carried out by Time Domain Reflectomety (TDR-300) instrument equipped with a $20 \mathrm{~cm}$ rod. Soil samples were collected along a 50 by50 $\mathrm{m}$ grid based treatment unit pattern.

Data was in all case collected with their geographical location by means of dGPS receiver, and saved into a file format which was applicable as an input into ArcView GIS software. In order to be able to compare the data, all measurement points were statistically analyzed for outliers by means of Grubbs-test, and integrated into the GIS software. Vector based point data was interpolated into a raster format with the aim of geostatistical comparison with the aerial hyperspectral image.

\section{Results and discussion}

Visual comparison of winter wheat yield and hyperspectral narrow band based Normalized Differential Vegetation Index map shows strong correlation (Fig. 1).
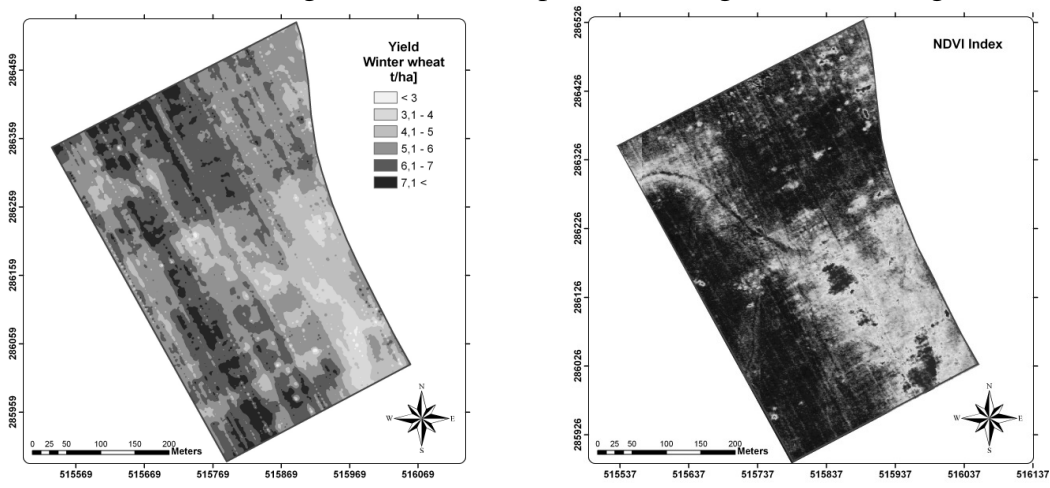

Figure 1. Yield map and narrow band NDVI index map of the investigated field. 
The pattern which appears in each year on the field can be very well seen on both pictures. As hyperspectral image was collected prior to harvest, yield estimation can be carried out based on the technology. Protein content map and NDVI map comparison did not show the same strong correlation, however data used for the interpolation was collected prior to calibration of the instrument. At the same time earlier results showed that correlation between protein content and other narrow band vegetation indexes than NDVI (in spring barley) can result stronger correlation than NDVI index and yield.

Soil parameter measurements were carried out by several methods. In this article only the soil moisture content comparison with the hyperspectral image is reported.

Topsoil water content which is measured by hyperspectral imaging showed similar pattern to the hand collected data (Fig. 2). In Figure 2 soil content measured by TDR method in the top $20 \mathrm{~cm}$ shows a relatively high water content in the north eastern corner of the investigated field, the similar pattern as the narrow band hyperspectral image on the $1460 \mathrm{~nm}$ wavelength. On the wavelengths mentioned in the literature, similarity was not as sure as on $1460 \mathrm{~nm}$.
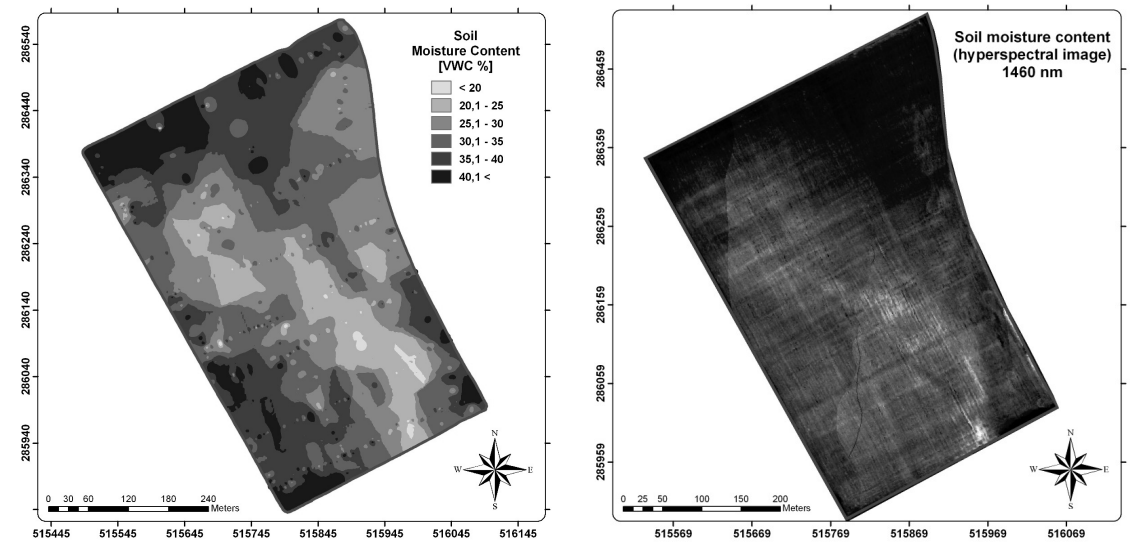

Figure 2. Soil moisture map and $1460 \mathrm{~nm}$ reflectance in the investigated field.

\section{Conclusions}

Comparison of various field measurements and hyperspectral images proved that there is a possibility of pattern recognition by the visualization of different wavelengths. Concerning the wide range of possibilities given by the high number of the variable wavelengths for vegetation index calculation geostatistical comparison can be carried out in order to decide the most precise indexes for vegetation analysis. As for soil moisture and other soil characteristic measurements it has to be taken into consideration that only the top soil surface information is provided by the hyperspectral image, however this information can be interdependent with different factors and can also be an indicator about the soil characteristics. 


\section{Acknowledgements}

Authors would like to thank for the support of the Bolyai János Research Scholarship of the Hungarian Academy of Sciences as well as the Hungarian Institute of Agricultural Engineering (FVMMI) and IKR Zrt. for their help with the sensing instruments and Trimble dGPS receiver.

\section{References}

Deákvári J. - Kovács L. - Papp Z. - Fenyvesi L. - Tamás J. - Burai P. - Lénárt Cs.: 2008. First results of AISA hyperspectral remote sensing application. MTA-AMB Kutatási és fejlesztési tanácskozás, 32 . in print.

Hargitai H. - Kardeván P. - Horváth F.: 2006. Az első magyarországi képalkotó spektrométeres repülés és adatainak elemzése erdőtípusok elkülönítésére. Geodézia és Kartográfia, 58. 9 .21-34.

Jung A.: 2005. Spektrális információk alkalmazása a városklíma-kutatásban. Doktori értekezés, Budapesti Corvinus Egyetem, Kertészettudományi Doktori Iskola, 131., online: www.lib.unicorvinus.hu/phd/jung_andras.pdf

Kardeván P. - Reisinger P. - Tamás J. - Jung A.: 2004. A parlagfü (Ambrosia artemisiifolia L.) reflektancia spektrumainak meghatározása terepi mérésekkel. Magyar gyomkutatás és technológia, V. 1. sz., 15-31.

Lihua Z. - Minzan L. - Jianying S. - Ning T. - Xijie Z.: 2005. Estimation of soil moisture with aerial images and hyperspectral data. Geoscience and Remote Sensing Symposium, 2005. IGARSS apos;05. Proceedings. 2005 IEEE International, Volume 6, Issue , 25-29 July 2005: 4516 - 4519.

Milics G. - Neményi M.: 2007. Adatgyüjtés müszaki és informatikai háttere. In: Németh T. - Neményi M. Harnos Zs. (ed.): A precíziós mezőgazdaság módszertana. JATE Press-MTA TAKI, Szeged, 139-159.

Milics G. - Burai P. - Lénárt Cs.: 2008a. Pre-Harvest Prediction of spring barley nitrogen content using hyperspectral imaging. Cereal Research Communications, 36, Akadémiai Kiadó, 1863-1866.

Milics G. - Burai P. - Lénárt Cs. - Tamás J. - Papp Z. - Deákvári J. - Kovács L. - Fenyvesi L. - Neményi M.: 2008b. Comparison of multispectral and hyperspectral vegetation indices for prediction of yield and grain quality of spring barley in Hungary. AgEng 2008 International Conference on Agricultural Engineering, Hersonissos, Crete 2008. június 23-25., Conference CD.

Nagy, V. - Stekauerová, V. - Milics G. - Lichner, L. - Neményi M.: 2008. Harmonisation of different measuring methods of soil moisture used in Žitný Ostrov (SK) and Szigetköz (HU). Cereal Research Communications, 36, 1475-1478.

Neményi M. - Milics G.: 2007. Precision agriculture technology and diversity. Cereal Research Communications. 35, 829-832.

Neményi M. - Nagy, V. - Stekauerová, V.: 2008. Limiting factors of precision farming - soil compaction and precipitation. Cereal Research Communications 36, 1859-1862.

Papp Z. - Fenyvesi L.: 2007. Új távérzékelési módszer a mezőgazdaságban és a környezetgazdálkodásban. Mezőgazdasági Technika, XLVIII 2007 január, 26-28.

Pechmann I. - Tamás J. - Kardeván P. - Vekerdy Z. - Róth L. - Burai P.: 2004. Hiperspektrális technológia alkalmazhatósága a mezőgazdasági talajvédelemben. in: Proc. EU Konform Mezőgazdasági és Élelmiszerbiztonság, 98-103.

Sanchez F.: 2003. Soil Moisture Estimation by Hyperspectral Remote Sensing in the Doode Bemde area in the valley of the Dijle River, Flanders, Belgium. Master thesis, 79

Tamás J. - Kardeván P. - Kovács E. - Kovács E. - Takács P.: 2005. Evaluation of environmental risks of non point source heavy metal contamination using DAIS sensor. In: Zagajewski, B. - Sobczak, M. - Wrzesień, M. (eds.): Proceedings of 4th EARSeL Workshop on Imaging Spectroscopy. New quality in environmental studies., EARSeL and Warsaw University, Warsaw, 415-423. 


\title{
CHALLENGES IN THE FIELD OF PLANT GROWTH AND DEVELOPMENT IN HUNGARY - EVALUATION AND ALTERNATIVES
}

\author{
Péter NÉMETH - Zsuzsanna TÓTH-NAÁR - Klára HUSTI-BÉRES- \\ Mahesh Kumar SINGH - Zsolt BARANYAI
}

Department of Economics, Faculty of Economics and Social Sciences, Szent István University. 2103 Gödöllő, Páter K. u. 1., Hungary. nemeth.peter@gtk.szie.hu

\begin{abstract}
The basic task of agricultural technical development is to increase resilience within agro-ecosystem in order to improve the efficiency of production procedure both in natural and economic sense. It is wellknown that the proper implementation of technical development imposes serious requirements towards agricultural plants which means significant challenges for the currently rather scattered but - at the same time - heterogeneous farms of the Hungarian plant structure. The current research examines the relations of natural efficiency on the database of the Research Institute of Agricultural Economics. According to the experiences, the natural efficiency of field crop production is mostly determined by the ecological condition system of farming. It indicates the need for crop production which corresponds to the land qualities in order to increase efficiency. The examinations have also identified the role of technical development factor as an important component, but pointed out that its function - besides ecological qualities - is supporting and complementing. Therefore, when managing this factor, the rationality is an important point in meeting the efficiency criteria in economic sense.
\end{abstract}

Keywords: Cobb-Douglas production functions, technical development, natural efficiency.

\section{Introduction}

The effectiveness of agricultural production - especially in field crop production - is significantly affected by a lot of environmental factors, due to its exposure. One of the highlighted tasks of agricultural technical development is to provide prevention from negative impacts and increase the resilience of the system through permanent development, perfection and harmonization of technical, biological, chemical and human factors.

The effect of elements of technical development put as input in field crop production can be measured the most directly through natural efficiency (yield per unit area) (Magó, 2008; Takács-György, 2008; Takács, 2007) It should be noted that the efficiency in economic sense (which can be expressed in the proportion of yield and input value) gives less reliable information due to the involvement of market conditions. It is obvious, however, that it is also significantly influenced by the operation of the system. In this approach it can be declared that the cautiously implemented technical development - by affecting the external factors which influence production considerably contributes to the competitiveness of agricultural enterprises (Figure 1).

It is important to make it clear in the relation of natural and economic efficiency that the natural efficiency does not always go together with economic efficiency, and it is true vice versa. The present paper discusses only the questions of natural efficiency.

The demand of improving the competitiveness of Hungarian agriculture has been stressed more and more by our days. The key element of competitiveness is efficiency. This paper intends to give some clues to this by exploring the relations and regularities of some factors of agricultural technical development and the output side. On the basis 
of the achievements we draw some conclusions concerning the future directions of development which basically would serve the improvement of efficiency.

\section{Materials and methods}

In our work we used data from primary source, which was made available to us by the Research Institute of Agricultural Economics (AKI). Out of the farm types represented in the Hungarian test farm network, the examinations were made on the individual data of farms specialised on the production of cereals, oilseeds and protein crops (1310 Specialist cereals (other than rice), oilseeds and protein crops). The analyses covered 6 years (2003-2008). The examined sample consisted of 791-874 farms each year.

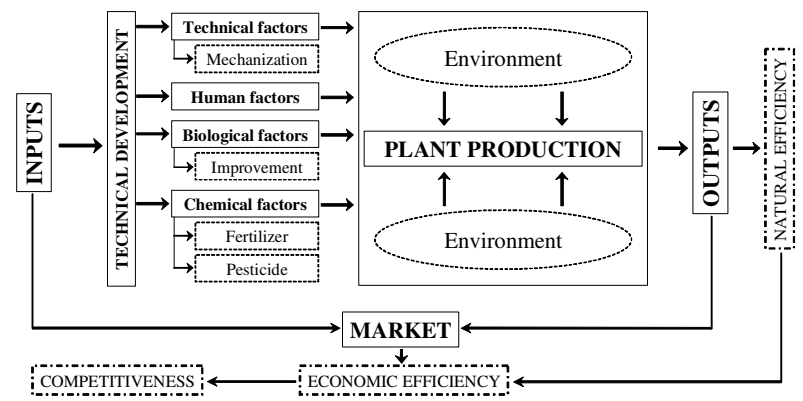

Figure 1. The main logical relations of research (Source: own construction)

On the basis of Figure 1 the problem can be approached mathematically with the following relation, by parametering the individual effective factors:

$$
\Phi(z H)=f\left(E(A), H(L), T(K), B\left(R_{1}\right), C\left(R_{2}, R_{3}\right)\right),
$$

where: $\Phi=$ natural efficiency of crop production, the standardized yield level index $(z H,-)$ was elaborated to express it (see later). $E=$ environmental indicator, gold crown value expressing the quality of arable land $(A, A K) . H=$ labour use on the farm $(H$, working hour $\left.\cdot h a^{-1}\right) . T=$ technical factor of technical development. Considering the specialities of the examined area, out of the technical pillar only the mechanization was examined. The size of capital locked in technical resources $\left(K, H U F \cdot h a^{-1}\right)$ was used for expressing the equipment supply in the farms. $B=$ biological basis. The level of this pillar of technical development was expressed with the value of propagation material use per unit area $\left(R_{l}, H U F \cdot h a^{-1}\right) . C=$ factors of chemical use. We calculated value indices per unit area in order to demonstrate the chemical use, by defining two areas: fertilizer use $\left(R_{2}, H U F \cdot h a^{-l}\right)$ and pesticide use $\left(R_{3}, H U F \cdot h a^{-1}\right)$.

The examined agricultural entreprises have rather diversified production structure, they simultaneously produced more crops in each production cycle. In order to obtain real comparison of natural yields on output side, we introduced the standardized yield level index $(z H)$ as an aggregated indicator, according to the following:

$$
z H=\sum_{i=1}^{n} \frac{a_{i}}{A} \cdot \frac{h_{i}-H_{i}}{S D_{i}}
$$


where: $a_{i}=$ area of crop culture No. $i$ [ha]; $A=$ total area of the given farm [ha]; $h_{i}=$ yield of crop culture No. $i$ in the farm $\left[\mathrm{t} \cdot \mathrm{ha}^{-1}\right] ; H_{i}=$ average yield of crop culture No. $i$ in the total sample $\left[\mathrm{t} \cdot \mathrm{ha}^{-1}\right] ; S D_{i}=$ dispersion of yield of crop culture No. $i$ in the total sample $\left[\mathrm{t} \cdot \mathrm{ha}^{-1}\right] ; n=$ number of crop cultures [pcs].

Cobb-Douglas $(C-D)$ type production functions - which are widespread in economic analyses - were applied for exploring the relations between the input and output side in agricultural plants. On the basis of this - referring to the above - the following production functions were determined in each year:

$$
z H=c \cdot A^{\alpha} \cdot L^{\beta} \cdot K^{\gamma} \cdot R_{1}^{\delta} \cdot R_{2}^{\varepsilon} \cdot R_{3}^{\varphi}
$$

Besides univariate methods (average and dispersion calculation, coefficient of variation (CV)) we also used multivariate methods (linear regression, ANOVA) in statistical analyses.

\section{Results and discussion}

The statistical examinations have made it obvious that the natural performance of agricultural production was mostly determined by the quality of the soil, as environmental condition system during the examined period (Table 1). This factor cannot be regarded as the element of technical development, but underlines that all the interventions which serve the improvement of land quality can be considered as successful tool of increasing efficiency. It is also important to stress on the basis of results, that out of the considered factors, the quality parameter of land was the element with the highest flexibility because its impact was the most solid (CV).

Table 1. Summarizing table of results of C-D function fitting (Source: own calculation)

\begin{tabular}{|c|c|c|c|c|c|c|c|c||c|c|}
\hline Years & $(\mathrm{c})$ & $(\mathrm{A})$ & $(\mathrm{L})$ & $(\mathrm{K})$ & $\left(\mathrm{R}_{1}\right)$ & $\left(\mathrm{R}_{2}\right)$ & $\left(\mathrm{R}_{3}\right)$ & Sum & $F$ szig. & $R^{2}$ \\
\hline \hline 2003 & $0.30^{* *}$ & $0.30^{* *}$ & -0.04 & 0.02 & $0.11^{* *}$ & $0.11^{* *}$ & $0.19^{* *}$ & 0.69 & 0.000 & 0.19 \\
\hline 2004 & 0.84 & $0.25^{* *}$ & $-0.03^{*}$ & $0.02^{*}$ & $0.08^{* *}$ & $0.07 * *$ & $0.05^{* *}$ & 0.44 & 0.000 & 0.19 \\
\hline 2005 & $0.65^{* *}$ & $0.23^{* *}$ & -0.03 & $0.04 * *$ & $0.06^{*}$ & $0.13^{* *}$ & $0.08^{* *}$ & 0.50 & 0.000 & 0.24 \\
\hline 2006 & $0.23^{* *}$ & $0.30^{* *}$ & 0.03 & $0.04 * *$ & $0.14^{* *}$ & $0.22^{* *}$ & $0.09^{* *}$ & 0.82 & 0.000 & 0.26 \\
\hline 2007 & $0.45^{* *}$ & $0.14^{* *}$ & -0.04 & 0.00 & $0.09^{*}$ & $0.25^{* *}$ & $0.09 * *$ & 0.53 & 0.000 & 0.16 \\
\hline 2008 & $0.56^{* *}$ & $0.24^{* *}$ & -0.01 & $0.02^{*}$ & 0.04 & $0.11^{* *}$ & $0.11^{* *}$ & 0.52 & 0.000 & 0.27 \\
\hline Mean & 0.51 & 0.24 & -0.02 & 0.02 & 0.09 & 0.15 & 0.10 & 0.58 & - & - \\
\hline CV & 0.45 & 0.25 & -1.50 & 1.00 & 0.33 & 0.47 & 0.50 & 0.25 & - & - \\
\hline
\end{tabular}

Remarks: * significant at the 0.05 level and ** significant at the 0.01 level.

A very interesting and important lesson have been found in connection with the role and relations of labour and capital. The analyses clearly showed the tendency that the increasing intensity of live labour use went together with decisively deteriorating production efficiency. It indirectly referred to the fact that the field crop production is a capital-consuming sector where the live labour is more efficiently replaced by dead 
labour. At the same time there was the paradox situation that the capital locked in production had quite modest impact on the results. This suggests that the technical factor is a ,quasi” minimum requirement for effective production but has no real impact on it (the extra input does not result extra yield). This fact highlights the necessity of rational management of this factor.

The experiences have proved that out of the further factors of technical development, the effect of chemical factors was the most significant on the yield realized in individual years. The role of fertilizer use could especially be highlighted. Although the performance of biological bases was more modest in this respect, but it was more stable system element concerning its flexibility.

Another very important result of our examinations was to demonstrate that the Hungarian agricultural enterprises operated with decreasing returns as regards the examined factors.

\section{Conclusions}

The results of the research - through the example of the Hungarian field crop farms have clearly proved the role of technical development in the improvement of resilience in agricultural ecosystem. The - not negligible degree of - own resilience of ecological factors, the flexible adaptation to the changing conditions and the control of external impacts is significantly assisted and stimulated by technical development.

According to the experiences, the resilience of ecosystems is considerably increased by "harmonization", that is production of crop varieties in accordance with the qualities of the production site. In the interest of increasing both the natural and economic efficiency it is strongly recommended to implement the criteria of harmonization in agricultural production.

The complementary function of technical development requires the rational management of its factors. It is an important criteria especially in the field of mechanization because its implementation in the current Hungarian farm structure faces a lot of difficulties. In our opinion, the cooperation of farmers - with flexible organisations - can be an adequate response to this problem in economic sense because this way the fulfillment of criteria of economic efficiency can also be ensured.

\section{Acknowledgements}

The research was carried out with the support of Szent István University, Faculty of Economics and Social Sciences, Institute of Economics and the Research Institute of Agricultural Economics.

\section{References}

Magó, L.: 2008. Low Cost Mechanisation for Efficient Land Use in Small and Medium Size Arable Farms. Cereal Research Communications, 36: 1111-1114.

Takács-György, K.: 2008. Economic aspects of chemical reduction on farming: role of precision farming will the production structure change? Cereal Research Communications, 36: 19-22.

Takács, I.: 2007. Factors of increasing of organic farming according to demand and supply. Cereal Research Communications, 35: 1173-1176. 


\title{
ECONOMIC ASPECTS OF TECHNOLOGICAL RESILIENCE - RISK OF PRECISION FARMING
}

\author{
Katalin TAKÁCS-GYÖRGY ${ }^{1}-$ István TAKÁCS $^{2}$ \\ ${ }^{1}$ Institute of Business and Organizational Management, Szent István University, H-2103 Gödöllő, Páter K. u. \\ 1. e-mail: takacsne.gyorgy.katalin@gtk.szie.hu \\ 2 Institute of Finance and Accountancy Szent István University, H-2103 Gödöllö, Páter K. u. 1. e-mail: \\ takacs.istvan@gtk.szie.hu
}

\begin{abstract}
Farms have to operate in their system environment in a way that they meet the three requirements of sustainability. However they can vary according to their resilience and adaptability to physical, ecological and economic changes which are determining factors. Precision farming is a technology that makes the sitespecific differentiated spread and, based on input and output prices, the optimized use of artificial fertilizers and herbicides possible due to the soil-ecosystem-species-technology system. The technology guaranteeing elasticity is expected to be spread widely once it is considered to be competitive from an economic point of view by the farmers themselves. During our former researches we found that weed management has greater effect on income among the technological elements. We analyzed the soundness and risk of precision weed management in case of different crops by conducting model calculations. It could be stated that heterogeneity of soil parameters and weed coverage, furthermore the changes in output prices significantly influence the economic justification and the risk of precision technology (weed management) Precision plant protection is a resilient and elastic technology that could be applicable at certain farming size and intensity under Hungarian circumstances, but economic justification does not always coincide with environmentally conscious farming.
\end{abstract}

Keywords: weed management, heterogeneity of weed coverage, economic return

\section{Introduction}

Key factor of adaption in agricultural production is the technology and its resilience respectively to its suitability for criteria of sustainability. Considering the sustainability from economic point of view the rationality of every new technological element must be examined. Precision plant production is a technology that allows the optimization of the site-specific use of artificial fertilizer and herbicide depending on soil - ecosystem crop species - technical background based on input and output prices. Precision plant protection is a suitable technology for reducing the chemical use, but its role must be emphasized in reducing yield uncertainty. Precision farming could be considered as a tool for increasing efficiency and at the same time it is a technology that reduces the burden of environment besides ensuring the economic efficiency.

The role of agricultural economists during the examination of applicability is to determine the circumstances under which the use of technology is profitable, while risk could be decreased. (Swinton and Lowenberg-DeBoer, 1998) Based on their results they could recommend suggestions for agricultural politicians. Some authors pointed out that additional inputs of precision plant production returned by increasing the size of application. (Batte, 1999; Neményi et al., 2001; Godwin et al., 2003; Székely et al., 2000; Takács-György et al., 2008; Takács-György and Takács, 2009)

Only a few authors have examined the economic effects of precision plant protection comparing with precision nutrition. A number of the authors established that there is higher input cost surplus than cost advantages due to pesticide savings so material savings and environment preserving effects of the technology must be put into focus. (Mesterházi et al., 2001; Barroso et al., 2004; Neményi and Milics, 2007) In relation to 
precision plant protection heterogeneity within the plot is of determining importance and also the site-specific recognition and treatment of weed covered cells from the point of weed management.

The aim of our research is to model and examine economic effects of precision plant protection. Its technical, technological background is given, its spread to come into wide general use is expected only if the complex precision plant production is competitive economically for the producers.

\section{Materials and methods}

As a result of our former researches we determined the optimal production structure after turning to precision plant production, the viable farm size that is necessary to cover the cost surplus connected to turning to new technology, while ensuring the return of capital investments, too. [Takács-György, 2008; Takács-György et al., 2008; TakácsGyörgy - Takács, 2009] The created simulation model operates the relations between inputs-outputs and income, based on classical production functions. The simulation model examines the expected dispersion (incidence frequency) in categories determined with normative classification of intensity of production and weed coverage with combinations generated by random number (Monte Carlo simulation), on damagethreshold respectively on giving up threshold, their variability due to the change of various factors depending on intensity, nutrition level, weed coverage and their heterogeneity in the plot. (Giving up threshold means the upper border of economic applicability of range.)

We made the calculations on three differentiated nutrition and weed coverage levels (low, middle and high) using three selling prices on maize (corn), examining the economic viability and applicability of precision plant production (precision technology).

During the economic calculations we do not differentiate precision fertilize use and precision weed management from each other, supposing that these two elements of precision technology is introduced at the same time.

\section{Results and discussion}

The economic justification and risk of three farming strategies could be distinguished 1. input (cost) minimalizing; 2. precision farming; 3. whole-surface damage minimalizing strategy - depending on nutrition level (based on soil features), weed coverage and selling price of yield (market conditions). Economic viability (justification) of precision farming depends on the available production value, the farm conditions, the ecological and soil potential, its heterogeneity and on the nutrition level as well as on the intensity of production, weed coverage and its heterogeneity.

Potential higher production value, higher nutrition level (intensity) serve as good reasons to turn to precision farming - they make the viable interval wider - and reduce the economic risk of this technology.

Increase of weed coverage - that is unfavourable scenario for farmers - takes the same effect by decreasing the economic risk of precision farming. With the help of the results of the simulation model a risk-matrix can be set up that shows the risk of return of 
turning to precision plant production. In case of low weed coverage weed management is not required as long as not reaching the damage threshold. Place and scale of damage threshold depends on current selling prices and it could be determined for the standard units (base units) of precision plant production on the bases of the site-yield loss production value and costs connected to the site treatment. If weed coverage is high and the numbers of cells, where the treatment is negligible, are low, the whole-surface treatment is proposed. In this case the surplus costs of necessary investment connected to precision weed management must also be evaluated. If the "rescued production value" ascribed to precision plant protection during the life time of the investment does not cover the above mentioned costs, the investment will not return. Of course in these cases turn to precision plant protection could happen not only based on economic considerations however substantial material savings in pesticides cannot be expected. If the above mentioned two scenarios do not occur, turning to precision plant protection will return economically, not even taking the role of precision farming in reducing environmental burden into consideration. (Tabel 1.)

Table 1. Economic risk of turning to precision plant production depending on soil features and weed coverage.

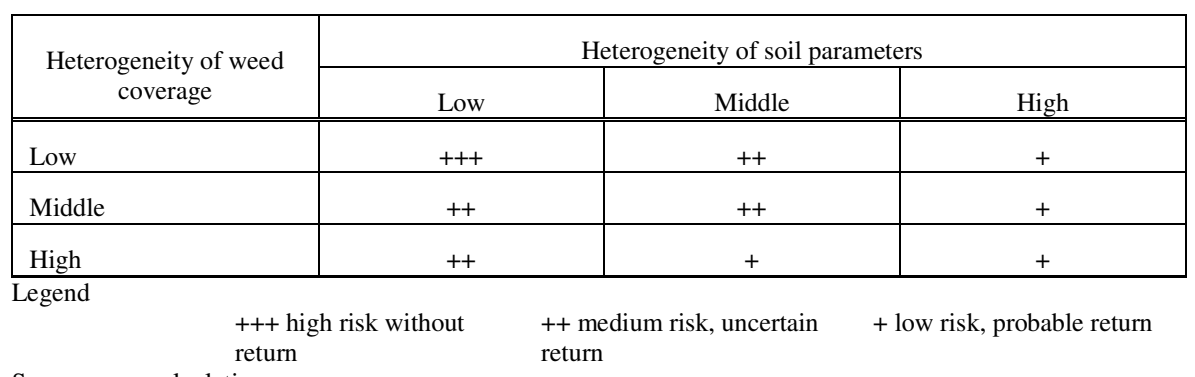

Source: own calculations

\section{Conclusions}

Economic applicability of precision technology depends on the level of nutriments of the soil, on the reaction of the species at a certain nutrition level (input - output relations), on weed coverage, on the competence between crop and weed, on the surplus costs of technology /or on the cost savings in different crops. The economic advantage of precision technology including precision weed management appears, if the heterogeneity of land is high that is in close relationship with the fact that in these cases the number of cells where the treatment is not necessary could be significant thus the value of herbicide savings could be high.

In case of homogenous land (smooth soil nutriment state, smooth weed coverage) the number of those cells where it is not necessary to use herbicides or fertilizers or the herbicide use is required (or not required) in different ways depending on soil parameters, the total, undifferentiated treatment is more profitable. Of course precision technology could also be used in these cases - taking into consideration of other advantages of precision farming that are not measurable today (e.g. external effects), its role in decreasing environmental burden -, but it must be admitted that it would not effect income surplus on farm level. At the same time it must be emphasized that 
benefits of precision technology on the long term originates from the site specific chemical use on environment conditions. It could be stated that heterogeneity of soil parameters and weed coverage and changes in selling prices has significant effects on economic justification and risk of precision weed management. Precision weed management is a resilience farming strategy that is suitable and profitable technology at certain farming size and intensity of crop production under Hungarian conditions, but economic justification does not always coincide with sustainable, environmental conscious farming.

\section{References}

Barroso, J. - Fernandez-Quintanilla, C. - Maxwell, B. D. - Rew, L. J.: 2004. Simulating the effects of weed spatial pattern and resolution of mapping and spraying on economics of site-specific management. Weed Research. 44. (6) 460-468.

Batte, M. T.: 1999. Precision Farming - Factors Influencing Profitability. The Ohio State University. Online: http://aede.osu.edu/Programs/VanBuren/pdf/PrecisionFarming.pdf. letöltési idő: 2007. április 25. 13.

Godwin, R. J. - Richards, T. E. - Wood, G. A. -Welsh, J. P. - Knight, S. M.: 2003. An Economic Analysis of the Potential for Precision Farming in UK Cereal Production. Online: https://de.scientificcommons.org/8488665 Letöltve: 2008. október 31. 29 .

Mesterházi P. Á. - Pecze Zs. - Neményi M.: 2001. A precíziós növényvédelmi eljárások müszakitérinformatikai feltételrendszere. Növényvédelem. 37 (6) 273-281 .

Neményi M. - Pecze Zs. - Mesterházi P. Á. - Németh T.: 2001. A precíziós - helyspecifikus növénytermesztés müszaki és térinformatikai feltételrendszere. Növénytermelés. 50. (4) 419-430 .

Neményi M. - Milics G.: 2007. Precision agriculture technology and diversity. Cereal Research Communacations. 35. (2) 829-832.

Swinton, S. M. - Lowenberg-DeBoer, J.: 1998. Profitability of site-specific farming. In: Site-specific management guidelines. SSMG-3 Online: http://www.inpofos.org; letöltve: 2008. február 25.4 p.

Székely Cs. - Kovács A. - Györök B.: 2000. The practice of precision farming from an economic point of view. Gazdálkodás. English Special Edition. 1. 56-65.

Takács-György K.: 2008. Economic aspects of chemical reduction in farming - future role of precision farming. Food Economics - Acta Agriculturae Scandinavica. Section C. 5. (2) 114-122.

Takács-György K. - Reisinger P. - Takács E. - Takács I.: 2008. Economic analysis of precision plant protection by stochastic simulation based on finite elements method. Journal of Plant Diseases and Protection. Stuttgart. Sp. XXI 181- 186.

Takács-György K. - Takács I.: 2009. Economic Analysis of Precision Weed Management. Cereal Research Communications. 37 (4) 597-605 


\title{
EFFECTS OF DIFFERENT INDUSTRIAL WASTES ON THE PLANT GROWTH AND DEVELOPMENT IN THE AGRO- ECOSYSTEM
}

\author{
Brigitta TÓTH - Nóra BÁKONY - Szilvia VERES
}

Department of Agricultural Botany and Crop Physiology, Institute of Plant Sciences, University of Debrecen, 4032 Debrecen, Böszörményi út 138. Hungary, btoth@agr.unideb.hu

\begin{abstract}
An agro-ecosystem can be characterized by a much simple composition of species living in the given system and by a simpler energy flow than a natural, stable ecosystem. Unthinking use of pesticides disturbs this balance due to the poisonous effect on several organisms in the soil.

The aim of this work is to give a brief overview of the effects of some industrial wastes (flue-gas dust, extruded poppy-heads). These materials contain lots of useful elements for plants (e.g. potassium, iron, phosphorous). But, their aluminium and chrome contents also are considerable. The dry matter accumulation and relative chlorophyll contents were measured. The flexibility of plant responses depends on composition, origin of examined wastes. Disadvantageous and advantageous physiological effects of flue-gas dust and extruded poppy-heads were proved. The compensation effect of environment is excluded, however, the neutralization of environment loads are not endless among natural circumstances.
\end{abstract}

Keywords: industrial wastes, plant growth and development

\section{Introduction}

Agro-ecosystem sustainability depends on the ability of farmers to maintain soil productivity. As plant nutrition issues are redefined by society, new applications emerge for a basic understanding of nutrient use-efficiency in soil-plant processes to avoid excess on rich soils (van Noordwijk, 2001). Over-application of fertilizers in poorly managed cropping systems can result in serious environmental problems, such as pollution of groundwater and eutrophication of surface waters (Socolow, 1999). In many developing countries with a tremendous requirement for food, continuous nutrient is flat and low usage of mineral fertilizers is the concerns, not the environmental pollution (Gruhn et al., 2000).

The global crisis in micronutrient deficiencies is the result of dysfunctional food systems that cannot deliver enough of these nutrients to meet the nutritional requirements of all throughout the year. Because agriculture is the primary source of all micronutrients for humans, agricultural systems must be contributing to this failure to meet nutritional needs (Welch et al., 1997). How can agriculture be change in ways that will result in enough micronutrient output of farming systems to assure adequate nutrition for all? Importantly, if agricultural technologies are directed at improving the nutritional quality of food crops, they must encompass a holistic food system perspective to assure that the planned interventions will be sustainable, and agriculture sector must adopt a specific goal of improving human nutrition and health, and the nutrition and health sectors must adopt agricultural interventions as primary tools to fight this growing crisis. All operation and methods, which try to reduce the pollution of food chain, have a main role in our life (Lévai et al., 2008). 
In this paper were investigated effect of flue-gas dust and poppy-head on concentration of elements ( $\mathrm{Al}, \mathrm{Cr}, \mathrm{K}, \mathrm{Na}, \mathrm{P}, \mathrm{Fe}$ ) and dry matter accumulation of the shoots and roots of sunflower seedlings and chlorophyll contents of sunflower $1^{\text {st }}$ leaves.

\section{Materials and methods}

Sunflower (Helianthus annus L. cvs. Arena) were used in the experiments. The seeds were sterilized with $18 \%$ hydrogen peroxide, and then washed in distilled water. Then they were germinated on moistened filter paper at $25{ }^{\circ} \mathrm{C}$. The seedlings were transferred to continuously aerated nutrient solution of the following composition: 2.0 $\mathrm{mM} \mathrm{Ca}\left(\mathrm{NO}_{3}\right)_{2}, 0.7 \mathrm{mM} \mathrm{K}_{2} \mathrm{SO}_{4}, 0.5 \mathrm{mM} \mathrm{MgSO}{ }_{4}, 0.1 \mathrm{mM} \mathrm{KH}_{2} \mathrm{PO}_{4}, 0.1 \mathrm{mM} \mathrm{KCl}, 1 \mu \mathrm{M}$ $\mathrm{H}_{3} \mathrm{BO}_{3}, 1 \mu \mathrm{M} \mathrm{MnSO}, 0.25 \mu \mathrm{M} \mathrm{CuSO}_{4}, 0.01 \mu \mathrm{M}\left(\mathrm{NH}_{4}\right)_{6} \mathrm{Mo}_{7} \mathrm{O}_{24}$. Iron was added to the nutrient solution as Fe-EDTA at a concentration of $10^{-4} \mathrm{M}$. The filtrates of flue-gas dust and extruded poppy-heads were added to the nutrient solution in different quantities. $82 \mathrm{ml} \mathrm{dm}^{-3}$ was given from the flue-gas dust and $91 \mathrm{ml} \mathrm{dm}^{-3}$ from the extruded poppy-heads to the nutrient solution because of different solution. The seedlings were grown under controlled environmental conditions (light/dark regime $10 / 14 \mathrm{~h}$ at $24 / 20^{\circ} \mathrm{C}$, relative humidity of $65-70 \%$ and a photosynthetic photon flux of $390 \mathrm{mEm}^{-2} \mathrm{~s}^{-1}$. The number of repetitions was three. The contents of elements were measured with ICP, the relative chlorophyll contents with SPAD 502 (Minolta). The samples were dried at $85 \mathrm{C}^{\circ}$, the dry matter of shoots and roots were measured.

The flue-gas dust originated from Hajdu Komm Environmental Protection Ltd. (Eastern Hungary) and the extrusion poppy-head came from Alkaloida Chemicals Co. Ltd. (East Hungary).

\section{Results and discussion}

The examined matters were produced in large quantity by the above-named companies. These materials contain lots of useful elements for plants (e.g. potassium, phosphorus, iron) and some harmful elements in addition (e.g. chrome, aluminium). The plants can uptake these elements and may cause different effects on the development and growth of plants. The up taken elements are shown in the Table 1.

Table1. Concentration of examined elements (Al, Cr, K, Na, P, Fe) in the shoots and roots of sunflower seedlings $\left(\mathrm{mg} \mathrm{kg}^{-1}\right)$ effecting by flue-gas dust and poppy-head

\begin{tabular}{|c|c|c|c|c|c|c|}
\hline \multirow{2}{*}{ Elements } & \multicolumn{2}{|c|}{ Controll } & \multicolumn{2}{c|}{ Flue-gas dust } & \multicolumn{2}{c|}{ Extrused poppy-head } \\
\cline { 2 - 7 } & Shoots & Roots & Shoots & Roots & Shoots & Roots \\
\hline \hline $\mathrm{Al}$ & 7.25 & 34.80 & 19.41 & 87.76 & 7.59 & 582.66 \\
\hline $\mathrm{Cr}$ & 1.20 & 1.22 & 0.54 & 1.20 & 0.59 & 1.16 \\
\hline $\mathrm{K}$ & $44,366.33$ & $58,219.67$ & $43,015.00$ & $84,413.00$ & $47,317.33$ & $55,937.00$ \\
\hline $\mathrm{Na}$ & 204.00 & $3,686.33$ & 216.00 & $2,786.67$ & 287.33 & $4,334.33$ \\
\hline $\mathrm{P}$ & $4,455.00$ & $7,148.33$ & $3,925.33$ & $4,472.67$ & $4,595.66$ & $7,294.00$ \\
\hline $\mathrm{Fe}$ & 117.33 & 454.33 & 91.63 & $4,901.33$ & 90.73 & 438.33 \\
\hline
\end{tabular}

Larger concentrations of aluminium were measured in the roots than in the shoots. We suppose that the $\mathrm{Al}$ were accumulated in the roots and the root- to- shoot transfer is retarded. The Al concentrations were highest in the roots of treated plants, and as a 
consequence the observed growth of the shoots and roots were over the control. The concentrations of $\mathrm{Al}$ were about 18 times higher than the control. The toxic effects of aluminium are primarily root-related (Taylor, 1988). The root system becomes stubby as a result of inhibition of elongation of the main axis and lateral roots (Klotz and Horst, 1988). The severity of inhibition of root growth is a suitable indicator of genotypic differences in aluminium toxicity (Foy et al., 1967). Aluminium toxicity is therefore often expressed simultaneously in two ways, namely induced deficiency of mineral nutrients, such as magnesium, and inhibition in root elongation (Tan et al., 1992).

The concentrations of chrome were below the control value in the shoots when flue-gas dust and extruded poppy-heads were added to the nutrient solution; these concentrations were lower in the shoots than in the control. The $\mathrm{Na}$ and $\mathrm{P}$ concentrations were lower in the shoots and roots when flue-gas dust was used and higher when the nutrient solution was completed with extruded poppy-heads. The quantities of $\mathrm{K}$ were extremely high $\left(84,416.00 \mathrm{mg} \mathrm{kg}^{-1}\right)$ in the roots of sunflowers when we treated them with flue-gas dust.

Differences were observed also in dry matter accumulation of sunflower seedlings during the experiment. The results are shown in Table2.

Table2. Effects of different matters (flue-gas dust, extruded poppy-heads) on the dry matter accumulation of shoots and roots of sunflower seedling $\left(\mathrm{g} \mathrm{plant}^{-1}\right) \mathrm{n}=3$

\begin{tabular}{|c|c|c|c|c|c|c|c|c|c|c|c|}
\hline \multicolumn{4}{|c|}{ Control } & \multicolumn{4}{c|}{ Flue-gas dust } & \multicolumn{3}{c|}{ Extruded poppy-head } \\
\hline \multicolumn{2}{|c|}{ Shoots } & \multicolumn{2}{c|}{ Roots } & \multicolumn{2}{c|}{ Shoots } & \multicolumn{2}{c|}{ Roots } & \multicolumn{2}{|c|}{ Shoots } & \multicolumn{2}{c|}{ Roots } \\
\hline Mean & S.D. & Mean & S.D. & Mean & S.D. & Mean & S.D. & Mean & S.D. & Mean & S.D. \\
\hline \hline 0.960 & 0.169 & 0.212 & 0.042 & 0.723 & 0.359 & 0.187 & 0.036 & 0.838 & 0.258 & 0.157 & 0.016 \\
\hline
\end{tabular}

In nearly all the cases, the values were below the control values. The dry matter of shoots and roots decreased when flue-gas dust and extruded poppy-heads were used.

Low chlorophyll contents affect photosynthetic activities. The decreasing dry matter accumulation can be explained by the lower level of the chlorophyll contents (Table3).

Table3. Relative chlorophyll contents of sunflower $1^{\text {st }}$ leaves on the measurement of $10^{\text {th }}, 13^{\text {th }}$ and $15^{\text {th }}$ days (Spad Units) $\mathrm{n}=35$

\begin{tabular}{|c|c|c|c|c|c|c|}
\hline \multirow{2}{*}{ Treatments } & \multicolumn{2}{|c|}{$10^{\text {th }}$} & \multicolumn{2}{c|}{$13^{\text {th }}$} & \multicolumn{2}{c|}{$15^{\text {th }}$} \\
\cline { 2 - 7 } & Mean & S.D. & Mean & S.D. & Mean & S.D. \\
\hline \hline Control & 47.5667 & 1.9255 & 50.6250 & 1.3419 & 50.3333 & 0.3987 \\
\hline Flue-gas dust & 46.1167 & 0.8567 & 46.4833 & 2.1538 & 44.4667 & 3.4388 \\
\hline Extruded poppy-head & 45.5000 & 2.9454 & 48.3583 & 0.8755 & 47.6750 & 0.9744 \\
\hline
\end{tabular}

When plants are grown under controlled conditions, cc. $80 \%$ of the iron is localized in the chloroplasts in rapidly growing leaves, regardless of iron nutritional status. Iron can be stored in plant cells in the stroma of plastids as phytoferritin (Seckbach, 1982). Its 
content is high in dark-grown leaves (up to $50 \%$ of the total iron), but rapidly disappears during re-greening (Mark et al., 1981), and remains very low in green leaves. The chlorophyll contents will be higher due to the higher iron contents (Machold, 1968).

The flue-gas dust and extruded poppy-heads contain some iron (contain of iron in fluegas dust: $2.362 \mathrm{mg} \mathrm{kg}^{-1}$ in the raw matter and $1.873 \mathrm{mg} \mathrm{kg}^{-1}$ in the filtrate; contain of iron in extruded poppy-heads are $181 \mathrm{mg} \mathrm{kg}^{-1}$ in raw matter and $258 \mathrm{mg} \mathrm{kg}^{-1}$ in the filtrate). The relative chlorophyll contents did not change between the $10^{\text {th }}$ and $13^{\text {th }}$ days (46 Spad Units) but later it was reduced when flue-gas dust was applied. The Spad Units were increased on the $13^{\text {th }}$ days in leaves treated with extruded poppy-heads, the relative chlorophyll contents decreased on the $15^{\text {th }}$ days.

\section{Conclusions}

The effects of the examined materials are particularly unravelled - supposedly- because of the potential compensation effects of soil micro organisms. The laboratory experiment has also evidenced the harmful effects of examined industrial side-products, but injurious deformations were not observed on the plants. Further examinations are needed to clarify the effects of applied matters on the plants and on the (agro) ecosystems.

\section{Acknowledgements}

I would like to say many thanks to those companies for their help that have made the examined materials available to us: Ore, Mineral and Waste Recycling Works of Borsod Private Company Limited by Shares, Hajdu Komm Environmental Protection Ltd., Alkaloida Chemicals Co. Ltd.

\section{References}

Foy, C.D. - Fleming, A. L. - Armiger, W.H.: 1967. Characterization of differential aluminium tolerance among varieties of wheat and barley. Soil Sci. Soc. Am. Proc. 31, 513-521.

Gruhn P - Goletti F - Yudelman M.: 2000. Integrated nutrient management, soil fertility, and sustainable agriculture: current issues and future challenges. Washington DC. International Food Policy Research Institute. Food, Agriculture and Environment Discussion Paper 32.

Klotz, F. - Horst, W.J.: 1988. Genotypic differences in aluminium tolerance of soybean (Glycine max.L.) as affected by ammonium and nitrate-nitrogen nutrition. J. Plant Physiol. 132, 702-707.

László Lévai - Szilvia Veres - Ilona Mészáros - Nóra Bákonyi - Éva Gajdos: 2008. Interaction between wood ash and bio fertilizer in crop nutrition. Proceedings. $43^{\text {th }}$ Croatian $\& 3^{\text {rd }}$ International Symposium on Agriculture, Opatija, Croatia, 544-547

Machold O.:1968. Einfluss der Ernährugsbedingungen auf den Zustand des Eisens in den Blättern, den Chlorophyllgehalt und die Katalase- souie Peroxydaseaktivität. Flora (Jena), Abt. A. 159, 1-25.

Mark F.van der - Lange T. de - Bienfait H. F.: 1981. The role of ferritin in developing primary bean leaves under various light conditions. Planta 153, 338-342.

Seckback J.: 1982. Ferreting out the secrets of plant ferritin- a review.J. Plant Nutr.5, 369-394.

Socolow R.H.: 1999. Nitrogen management and the future of food: Lessons from the management of energy and carbon.Proc. Natl.Acad. Sci. USA 96, 6001-6008.

Tan, K. - Keltjens, W. G. - Findenegg, G.R.: 1992. Aluminium toxicity with sorghum genotypes in nutrient solutions and its amelioration by magnesium. Z. Pflanzenernähr. Bodenk. 155, 81-86.

Taylor, G.J.:1988. The physiology of aluminium phytotoxicity. In 'Metal Ions in Biological Systems' (H. Sigel and A. Sigel, eds.) 24, 123-163. Marcel Dekker Inc. New York

Van Noordwijk M . :2001. Plant nutrition: its role in sustainability of simple and complex agro-ecosystems. In Plant nutrition- Food security and sustainability of agro-ecosystems. 2-3.

Welch R.M. - Combs G.F.Jr. - Duxbury J.M.:1997. Towards a "greener". Revoulution Issues in Sciences and Technology, 14, 50-58 


\title{
ENVIRONMENTAL SECURITY
}

\author{
Bela MARKÓ ${ }^{1}$ - András MOLNÁR ${ }^{2}$ - József POPP ${ }^{2}$ \\ ${ }^{1}$ Hungarian Academy of Sciences, H-1051 Budapest, Nádor u. 7. e-mail: marko@ office.mta.hu \\ ${ }^{2}$ Research Institute for Agricultural Economics, H-1093 Budapest, Zsil u.3/5.E-mail: popp.jozsef@aki.gov.hu \\ ,molnar.andras@aki.gov.hu.
}

Abstract: Mankind is directly influenced by the loss of biodiversity. Biodiversity directly contributes to such essentials like clean water and air and fertile soil; it protects us from floods and avalanches. These benefits can all be valued economically. It is a difficult and complex task, but such a valuation would clearly show how important biodiversity is for human wellbeing and economic development. Many people are unaware of the speed with which we are consuming our natural resources. We are producing waste far faster than it can be recycled. It is important to compare the needs for public goods and services with arguments whether or not market failures are linked to the provision of such services. Corrections of market failures may also be achieved through investments and the provision of payments to reward land managers who provide public goods and services. It is important to demonstrate the economic value of ecosystem goods and services. The consensus about the importance of incorporating these "ecosystem services" into resource management decisions is increasing, but quantifying the levels and values of these services have been proven to be difficult.

Keywords: natural resources, public goods, environment, ecosystem, biodiversity

\section{Introduction}

We now know that the [over] exploitation of our entire ecosystem and the depletion of natural resources (the reserve-to-production ratio of oil reserves is rapidly declining) carry a price that must be paid today to compensate future generations for the losses (or costs of substitution) they will face tomorrow. Because the scarcity of emission rights has been recognized, an active market has been created in the EU and in the U.S. In the U.S. more regional cap and trade markets for $\mathrm{CO}_{2}$ have been created and are in process of development elsewhere. The natural resource scarcity issues are entirely real. Over the long term, environmental security is the mirror image of food security, because we have no food without substantial clean water resources, productive soils, and appropriate climate. In turn, failure to tackle environmental degradation jeopardizes the future of agriculture and land use (Lal et al., 2010). Climate change subjects all businesses and society in general to cumulative, long term risk. The failure of agriculture alone would lead to widespread hunger in developing countries and mass migration of people, mostly to developed countries.

\section{Materials and methods}

Joseph Stiglitz and Nicholas Stern made a joint appeal to use the financial crisis as an opportunity to lay the foundations for a new wave of growth based on technologies for a low carbon economy (Financial Times, 2009). Estimating the value of ecosystem services is controversial. Whatever the difficulties in measuring the value of the ecosystem services, the few studies undertaken so far, which are reviewed in this paper, indicate that that value could be colossal, and that the welfare losses of their degredation are huge. The results of these studies, with all their uncertainties, suggest that the gross value of environmental services may well be of comparable order of magnitude as the value of conventionally measured goods and services in the economy. In addition to that 
the paper stimulates a look at various ways of trying to bring about the delivery of these services.

\section{Results and discussion}

Through the extinction of species, we lose crucial opportunities to solve many problems of our society. Biodiversity provides us directly with essentials like clean water and air and fertile soil; it protects us from floods and avalanches. These benefits can all be valued economically. It is a difficult and complex task, but such a valuation would clearly show how important biodiversity is for human wellbeing and economic development (Table $1)$.

Table 1. Environmental Scenario to 2050

\begin{tabular}{|c|c|c|c|c|c|c|}
\hline & 2000 & 2010 & 2050 & \multicolumn{3}{c|}{ Difference } \\
\hline Use & \multicolumn{3}{|c|}{ Million Km² } & 2000 to 2010 & 2010 to 2050 & 2000 to 2050 \\
\hline \hline Natural areas & 65.5 & 62.8 & 58.0 & $-4 \%$ & $-8 \%$ & $-11 \%$ \\
\hline Bare natural areas & 3.3 & 3.1 & 3.0 & $-6 \%$ & $-4 \%$ & $-9 \%$ \\
\hline Managed forests & 4.2 & 4.4 & 7.0 & $5 \%$ & $62 \%$ & $70 \%$ \\
\hline Extensive agriculture & 5.0 & 4.5 & 3.0 & $-9 \%$ & $-33 \%$ & $-39 \%$ \\
\hline Intensive agriculture & 11.0 & 12.9 & 15.8 & $17 \%$ & $23 \%$ & $44 \%$ \\
\hline Woody biofuels & 0.1 & 0.1 & 0.5 & $35 \%$ & $437 \%$ & $626 \%$ \\
\hline Cultivated grazing & 19.1 & 20.3 & 20.8 & $6 \%$ & $2 \%$ & $9 \%$ \\
\hline Artificial surfaces & 0.2 & 0.2 & 0.2 & $0 \%$ & $0 \%$ & $0 \%$ \\
\hline World Total & 108.4 & 108.4 & 108.4 & $0 \%$ & $0 \%$ & $0 \%$ \\
\hline
\end{tabular}

Source: Braat, L., and Brink, ten P., Eds. 2008. Contribution of Different Pressures to the Global Biodiversity Loss between 2000 and 2050 in the OECD Baseline: Interim Report. Brussels: The Economics of Ecosystems and Biodiversity (TEEB).

It is important to demonstrate the economic value of ecosystem goods and services. We must know the costs and also be assured that the benefits are greater than the costs. The consensus about the importance of incorporating these "ecosystem services" into resource management decisions is increasing, but quantifying the levels and values of these services has proven difficult (Amstrong-Brown et al., 2009). Our searches revealed a disappointingly small set of attempts to measure and value these services. The earliest was the quantification of global ecosystem services (Constanza et al., 1997). Estimates of values based on willingness to pay for a hectare's worth of each of the services were extracted from the literature and expressed in 1994 U.S. dollars per hectare. The central estimate of the total value of annual global flows of ecosystem services in the mid 1990s was $\$ 33$ trillion; the range was thought to be $\$ 16$ to 54 trillion. To put their figure into some kind of context, the central estimate was 1.8 times larger than the than global gross domestic Product (GDP) at that time. The authors noted the huge uncertainties involved in making calculations of this kind.

The Stern Review (2006) parallels the TEEB report (European Commission, 2008). Climate change will exert very serious impacts on growth and development. The costs 
of stabilizing the climate are significant but manageable; delay would be dangerous and far more costly. The review estimates that if we fail to act, the costs and risks of climate change will be equivalent to losing at least $5 \%$ of global GDP each year, now and forever. In contrast, the costs of action - reducing GHG emissions to avoid the worst impacts of climate change - can be limited to around 1\% of global GDP each year. Key to understanding the conclusions is that as forests decline, nature stops providing services it provided essentially at no cost. Thus the human economy must step in to provide them, for example, by building reservoirs, building facilities to sequester carbon dioxide, and farming foods that were once naturally available.

The "Living Planet Report" of the World Wildlife Fund (WWF, 2008) demonstrates that humans live far beyond the capacity of the environment to supply us with services and absorb our waste and expresses the concepts of ecological footprints and biocapacity as hectares per person. ${ }^{1}$ Humanity's footprint first exceeded global biocapacity in 1980 and the overshoot has increased regularly since then. In 2005, the WWF calculated the average global footprint across the world was 2.7 global hectares (gha) per person ${ }^{2}$ a compared to a biocapacity calculated as 2.1 gha person $^{-1}$ a difference of $30 \%$. That means each person on earth consumes on average $30 \%$ more resources and waste absorption capacity than the world can provide.

The TEEB study of "The Economics of Ecosystems and Biodiversity" concerns the struggle to find the value of nature (European Commission, 2008). At present, about 100,000 terrestrial protected areas cover $11 \%$ of the earth's land mass. These protected areas provide ecosystem services and biodiversity benefits valued at $\$ 4.4$ trillion to $\$ 5.2$ trillion (a million millions) per annum. If you want a comparison, that amount is more than the revenues of the global automobile, steel, and IT services sectors of the economy combined! Calculations show that the global economy is losing more money from the disappearance of forests than through the current banking crisis. Forest decline costs about $7 \%$ of global GDP, putting the annual cost of forest loss between $\$ 2$ trillion and $\$ 5$ trillion, based on adding the values of the various services that forests perform, (providing clean water and absorbing carbon dioxide). However, the cost falls disproportionately on the poor, because more of their livelihoods depend directly on forests, especially in tropical regions. The greatest cost to Western nations would initially come from loss of a natural absorber of the most important GHG (European Commission, 2008).

The Global Canopy Programme's report concludes: "If we lose forests, we lose the fight against climate change." International demand has driven intensive agriculture, logging and ranching, leading to deforestation. Standing forest was not included in the original Kyoto Protocol and stands outside the carbon markets. The inclusion of standing forests in internationally regulated carbon markets could provide cash incentives to halt this disastrous process. Marketing these ecosystem services could provide the added value forests need and help dampen the effects of industrial emissions. Countries wise enough

\footnotetext{
${ }^{1}$ The ecological footprint measures the "biologically productive land and water area required to pro-duce the resources an individual, population or activity consumes and to absorb the waste it generates, given prevailing technology and resource management" (WWF, 2008).

${ }^{2}$ A global hectare has a global average ability to produce resources and absorb wastes.
}

611 DOI: 10.1556/Novenyterm.59.2010.Suppl.6 
to have kept their forests may find themselves the owners of a new billion dollar industry (Parker et al., 2008).

Creating markets for environmental services is not an entirely novel idea. Governments play a central role in setting them up, as has been done already for water quality trading, carbon trading, and wetland damage mitigation. In essence, legally binding caps on emissions (water and carbon) or mandatory replacement of lost biodiversity (wetland damage mitigation) create the demand needed to support a market for environmental services (Ribaudo et al., 2008). Mandatory cap and trade programs have been introduced in the northeastern U.S. and the EU. The U.S. and Australian governments intend also institute mandatory cap and trade programs to create financial incentives to limit energy use and reduce emissions. A national cap and trade program could establish a national market for carbon credits. Other markets such as water quality trading or wetland damage and/or loss mitigation may be limited to a few specific geographic areas.

\section{Conclusions}

Although ecosystems markets can play a significant role in order to reach sustainable biodiversity management, the role of government intervention to correct market failures will remain important. As an example, countries and companies with significant carbonsink potential would benefit. Conversely applying the polluter must-pay principle, $\mathrm{CO}_{2}$ emitters would pay to continue their emitting activities. The concept of limiting capping, auctioning, and trading emission, access, and user rights must be further developed beyond $\mathrm{CO}_{2}$, to include water and other resources on a worldwide scale. Valuing our ecosystems and regulating the access thereto will create a market for payment for ecosystem access entitlements and services with widespread involvement of private and public stakeholders.

\section{References}

Amstrong-Brown, S. - Baldock, D. - Bielenberg, N. - Brouwer, F. - Buckwell, A. - Cooper, T. - Erjavec, E. - Heiseenhuber, A. - Van Ittersum, M. - Heckelei, T. - Mantino, F. - Natta, G. - Nowicki, P. - PirzioBiroli, C. - Popp, J. - Swinnen, J.: 2009. Public goods from private land, Brussels, 2009. 66.

Costanza, R. - d'Arge, R. - de Groot, R. et al.: 1997. The value of the world's ecosystem services and natural capital. Nature 387: 253-60.

European Communities.: 2008. The economics of ecosystems and biodiversity (TEEB): an interim report, Brussels. Resources. http://ec.europa.eu/environment/nature/biodiversity/economics/index_en.htm

Joseph Stiglitz - Nicholas Stern.: 2009. Obama's chance to lead the green recovery, Financial Times, Published: March 2 2009, http://www.ft.com/cms/s/0/7c51644a-075b-11de-9294000077b07658.html?nclick_check=1

Parker, C. - Mitchell, A. - Trivedi, M. - Niki, M.: 2008. The Little Reed Book. (Reducing Emissions from Deforestation and (Forest) Degradation: Reed). Global Canopy Programme, Oxford. Published by: John Krebs Field Station.

Ribaudo, M. - LeRoy, H. - Hellerstein, D. - Greene, C.: 2008. The use of market to increase private investment in environmental stewardship, USDA-ERS

Stern, N.: 2006. Stern Review: The Economics of Climate Change. Cambridge, UK: Cambridge University Press. 2006. 


\title{
IMPLEMENTATION AND RESILIENCE OF TRADITIONAL PRODUCTS WITHIN AGRO-ECOSYSTEMS
}

\author{
Krunoslav ZMAIĆ - Tihana SUDARIĆ - Ružica LONČARIĆ
}

Department of Agroeconomics, Faculty of Agriculture, University of J.J. Strossmayer, Trg Sv. Trojstva 3, HR-31000 Osijek, Croatia, e-mail:kzmaic@pfos.hr

Abstract: Modern agricultural production tries to decrease cost production via using natural resources' energy, avoiding environment pollution considering and, at the same time, to not endanger high production yields. This kind of production, which dominates in intensive agriculture, is also called agro-ecological economy. Implementation of traditional agricultural production represents one of the key factors in agroecosystem process considering authenticity of land cultivation. Traditional production is multi-functional and it has economical importance in development of tourism in the County of Vukovar-Srijem. Traditional production is organized on family farms with small production volume targeted mostly for auto-consumption and market supply of these products is limited. This paper will determinate possibilities and limitations of resilience of traditional products in agro-ecosystem taking into account limitation of traditional production in the County of Vukovar-Srijem. Moreover, paper will also offer measures for these actions. Evaluation of traditional products is conducted regarding two criteria groups: commercialization potential and benefit for rural area. Average grade for all respondents is calculated according to weighted criteria significance. Optimal economical-organizational model will be recommended for implementation and resilience of traditional products which has market perspective and higher income potential perspective. Thereby this paper will offer background for commercialization of traditional agricultural products as products of added value.

Keywords: implementation and resilience, traditional production, agro-ecosystem

\section{Introduction}

Croatian rural area is ecologically preserved and consequently one of the most important available wealth, therefore it should be recognized as inheritance we should preserve for the future. Central place in rural area belongs to agriculture and in the order to increase competitiveness of this sector the revitalizing of rural policy is more important than market policy. Sustainable development based on diversification makes evaluation divergent of biological diversity dealing with agro-ecological system. Agricultural variations related to plant and animal species and flora and fauna are part of agricultural-ecosystem for higher economic, ecological and social wealth. Spreading of tradition production represents challenge for researches and policy creators to go out of traditional discipline and to seek more practical and more efficient interdisciplinary solutions. In order to respond those challenges it is necessary to understand ideas and experience among researches, resource managers, industry and environment protection in respect to more successful maintaining and sustainable management of traditional production, revitalization and family farm support. It is significant maintaining agricultural bio-diversity as well as their contribution for nature, environment and cultural inheritance. Traditional agricultural production is one of the key ecological processes because it has ecological and economical importance in the County of Vukovar-Srijem. Products came out from traditional agriculture through adding their values can become significant source of income and employment for numerous agricultural farms in the County of Vukovar-Srijem. 


\section{Materials and methods}

Traditional agricultural products include primary agricultural products produced by traditional procedures: soil tillage and traditional derivates. Demand for recognizable products and added value products constantly increases. Identifying factors connected to consumers' attitudes and preferences for preparing such product for market is very important. Research and evaluation of ideas for traditional products is conducted according to two groups of criteria related to commercialization potential and utility in rural area. Potential for commercialization is evaluated through following criteria: authenticity of product, quality, natural conditions for production, production experience, and knowledge of production. Utilities for rural area is evaluated through criteria: family farm employment, environmental preservation, economic efficiency, required period for production start up\&selling and building image of production area. In evaluation process are used assessments from 1-3 where 1 is the lowest value and 3 the highest value of assessment. Based on evaluation of above listed criteria, the average assessment of all criteria's assessment was calculated. The average assessments were pondered according to assessment importance.

\section{Results and discussion}

Production in rural areas should be economic efficient, ecologically accepted, social justified and technologically up to date. Traditional products are adjusted in a global strategy of sustainable development, considering possibilities for revitalization and rural development, systematic entrepreneurship, networking as well as creating more favorable environment via increasing income and creating local, regional, national and international partnership. Area specificity, cultural inheritance and tradition are combined by traditional products with their specificity and diversity compared to other food product of the same category. Unlike modern agricultural production and processing, traditional agriculture is based on authentic soil tillage, autochthon crops and livestock breeds, much more human labor, minimum of chemicals, homemade seeds, seeding material, traditional processing procedure, using nature spices and additives in processing of primary agricultural products. In order to determinate production\&economical factors of traditional products detailed questionnaire was conduced in the County of Vukovar-Srijem based on selected product for commercialization. Using questionnaire in the County of Vukovar-Srijem the majority of researched family farms had more than one traditional product. Farms are mostly led by male farmers, but female farmers were in charge for farm production due to traditional specificity. Therefore, the similar share of male and female $(53 \%$ versus $47 \%$ ) were defined. According to respondents' age, the most respondents were in group about 53 years, $25 \%$ in the group up to 45 years as well as in the group above 62 years. Majority of family farms had 4 members (average 4.18), 2.65 active members what amounts $63.40 \%$. According to respondents' education, majority of examinees had primary school degree $(52.5 \%)$ followed by examinees with high school degrees $(42.6 \%)$

From organizational state point, the most numerous were classic farms (agricultural or family farms not registered as company or craft) $-49.3 \%$, while the rest were farms under VAT system (11.2\%), crafts and companies (35.1\%). 33\% of examined farms were registered in National register. $15 \%$ are not listed in National register of 
agricultural producers while $2 \%$ didn't answered the question. Among farms listed in National register $50.9 \%$ had status as commercial farms, which mean that they are able to achieve government support for production according to the legislation. Other farms are non-commercial or they are in income support system.
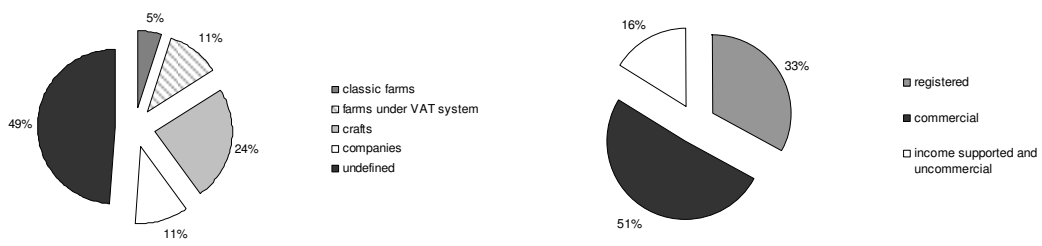

Figure 1. Status of agricultural households

Production structure in agriculture households shows that the most of examinees practice crop and live stock production (value 3). Processing on farms is evaluated as the most important farm activity (evaluated as 4), based on diversification and processing of crops and live stocking production.

Table 1. Importance of productions on farm (frequency of values 3 and 4 according to importance)

\begin{tabular}{|l|c|c|}
\hline \multirow{2}{*}{ Type of production } & \multicolumn{2}{|c|}{ Frequency of appearance } \\
\cline { 2 - 3 } & Value 3 & Value 4 \\
\hline \hline Live stock breeding & 7 & 4 \\
\hline Crop production & 5 & 5 \\
\hline Processing of farm & 4 & 10 \\
\hline Divers production & 2 & 2 \\
\hline
\end{tabular}

Researched traditional productions include following categories of products: processed products, handicrafts products, products of traditional crafts and traditional food and beverages. The total sum of points of specific products is obtained according to pondered average assessments and their summing. Five the most important traditional products are selected by ranking of products in accordance with number of points and commercial potential criteria. After that, those products are evaluated by criteria of utility for rural area. Result analysis of evaluated products showed that listed five products have important authenticity for the County of Vukovar-Srijem as well as utility for rural area and great commercialization potential. The highest potential for commercialization has kulen sausage \&sausages and honey products, while home-made cheese and home-made marmalade have highest utility for rural area. Maintaining and development of traditional production on one hand and the lack of entrepreneurial and management potential in domestic population on the other, indicates a need of further investments in marketing strengthening, such as: development of labeled products, planning, encouraging and supervision of traditional production, organization of own sale network for products, marketing, promotion and selling of touristic services etc. 


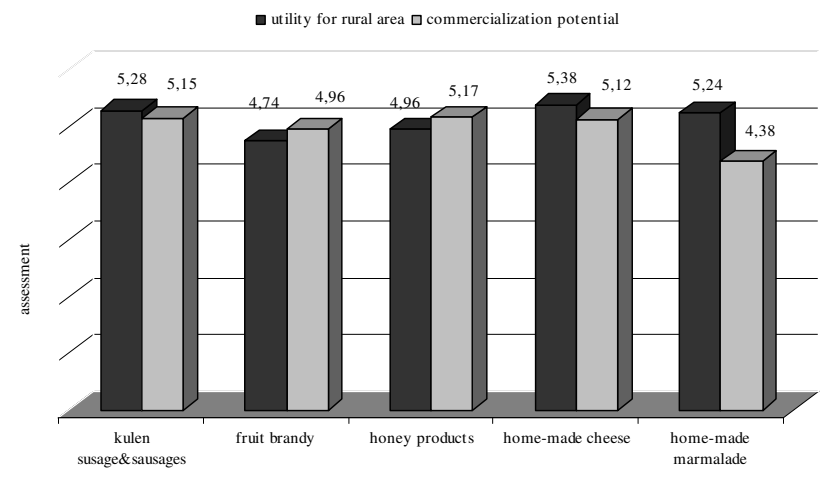

Figure 2. Agricultural household status

\section{Conclusions}

Gradual change of agricultural policy towards sustainable and integrated rural development through new concepts and instruments of multi-functional development represents a chance for development of traditional products in the County of VukovarSrijem. Traditional products are not self-sufficient on domestic market and they are strategically important in further development of rural entrepreneurship and export as well. In order to improve quantity of products and services of traditional products' supply it is necessary to adjust entrepreneurial marketing to targeted market segment. Furthermore, via improvement of product's quality and services on farms it is recommended to create models for encouraging traditional production, to adjust law regulation and to introduce standardization. It will bring the further development of traditional product on farms and will be the way of increasing competitiveness of total Croatian agriculture.

\section{Acknowledgements}

The paper is written within the project Evaluation model of traditional products in the County of Vukovar-Srijem financed by Ministry of agriculture, fishery and rural development, measure Marketing preparation of agricultural and food products. Specially, we want to thank the County of Vukovar-Srijem and Department for agriculture on full scale help and understanding regarding importance and role of traditional products in affirmation of rural area.

\section{References}

Altieri, M., - C. Nicholls: 2006. Agroecology and the search for a truly sustainable agriculture, Berkeley, CA, USA, University of California. 290.

Ellis, F.: 2000. Rural Livelihoods and Diversity in Developing Countries, Oxford University Press: Oxford and New York

Romero, C. - Rehman, T.: 1989. Multiple Criteria Analysis for Agricultural Decisions, Developments in Agricultural Economics, 5 Elesevier

Vasary, M.: 2007. Sustainable agriculture: with or without subsides? Cer. Res. Com., 35: 2.

Zmaic, K. - Sudaric, T - Arežina, M.: 2008.The Aspects of Agricultural Production Serving as a Function of Sustainable Development of the Vukovar-Srijem county, Cereal Research Communications, Proceedings of the VII. Alps-Adria Scientific Workshop, Stara Lesna, Slovakia 


\title{
INTERACTION OF RAINFALL, NUTRIENT INPUTS AND THEIR EFFICIENCY ON WHEAT YIELDS UNDER INTEGRATED AND ECOLOGICAL SYSTEMS
}

\author{
Magdaléna LACKO-BARTOŠOVÁ ${ }^{\prime}-$ Paul KRISTIANSEN ${ }^{2}$ \\ ${ }^{1}$ Department of Sustainable Agriculture and Herbology, Slovak University of Agriculture, Tr. A. Hlinku 2, \\ 94976 Nitra, Slovak Republic, magdalena.lacko-bartosova@uniag.sk \\ ${ }^{2}$ School of Environmental and Rural Science, University of New England, Armidale 2351, Australia
}

Abstract: As agriculture faces increasing economic and environmental pressure to use inputs efficiently, the need to evaluate not just absolute productivity, but also efficiency of farming systems also grows. A long-term trial comparing ecological (ECO) and integrated (INT) farming systems was carried out in western Slovakia, with kernel count, 1,000 grain weight (TGW) and grain yield of winter wheat being reported here. The ECO system had lower yields $(12-31 \%)$ in most, but not all, years. There was no difference in yield between farming systems during drier years. However, the greater productivity of the INT system was achieved with significantly lower nutrient efficiency for nitrogen, phosphorus and potassium inputs. The results indicate increased drought tolerance in the ECO system, possibly due to improved nutrient cycling and water-holding capacity, and because synthetic fertilizer inputs were less effective when rainfall was low. Ecological farming systems have the potential to achieve consistent, moderate yields with a significantly lower reliance on external inputs and under sub-optimal climatic conditions.

Keywords: wheat, fertilisation, efficiency, ecological, organic, integrated farming systems

\section{Introduction}

Agriculture is faced with a context of increasing policy requirements to minimise offfarm impacts (OECD, 2004), rising fertiliser and other input costs (Kudsk and Streibig, 2003), and growing global demand for 'green' produce with potential health and environmental benefits (Willer et al., 2008). Possible options to address these issues include ecological (organic) and other low external input farming systems such as integrated cropping systems. However, the productivity and efficiency of these systems depends on many site-specific factors such as soil fertility, climate, economics, and management style (Czapka, 2005 a,b; Cookson et al., 2006). This paper reports on the effects of ecological and integrated farming systems, fertiliser inputs and climatic variation on the yield of winter wheat in a long-term field trial.

\section{Materials and methods}

A series of rotation and cropping system field experiments were carried out at Dolná Malanta, Western Slovakia $\left(18^{\circ} 9^{\prime} \mathrm{E}, 48^{\circ} 19^{\prime} \mathrm{N}\right)$ from 1999 to 2008 . The location has a continental climate, with average temperatures of $19.7^{\circ} \mathrm{C}$ in July and $-1.7^{\circ} \mathrm{C}$ in January, and an average annual precipitation of $561 \mathrm{~mm}$ and the soil type is a Haplic Luvisol. A split-plot design was used with two main treatments, Ecological (ECO) and Integrated (INT) farming systems. Subplots were fertilised (+FERT) and unfertilised treatments (FERT), however, only the +FERT treatments are presented here. The ECO system was composed of a six stage crop rotation beans + lucerne - lucerne - winter wheat - peas maize - spring barley. The INT system consisted of the following crop rotation, winter wheat - peas - winter wheat - maize - spring barley - lucerne. The second winter 
wheat crop in INT was taken into evaluation. The +FERT treatment in ECO was based on 40 tonnes ha ${ }^{-1}$ of manure ( $\left.32.0 \mathrm{~N}, 6.7 \mathrm{P}, 34.7 \mathrm{~K} \mathrm{~kg} \mathrm{ha}^{-1}\right)$, while the INT system also received 40 tonnes $\mathrm{ha}^{-1}$ of manure plus synthetic fertiliser detailed in Table 1. Treatments were replicated four times. In order to compare the efficiency of the two farming systems, the yield parameters, kernel count (KC), 1,000 grain weight (TGW) and grain yield were divided by the volume of fertiliser added $\left(\mathrm{kg} \mathrm{ha}^{-1}\right.$ of nitrogen, phosphorus and potassium) in the +FERT treatments. Sowing and harvesting dates and climatic data during the winter wheat phase are shown in Table 1. Analysis of variance was used to identify significant treatment effects. Diagnostic plots were used to check normality and variances. No transformations were necessary. Significantly different means were separated using contrast analysis.

Table 1. Crop management data for winter wheat grown at Dolná Malanta, Slovakia, 1999-2006: sowing and harvesting dates; rainfall and average temperature calculated for the vegetative period of the crop; and synthetic fertiliser inputs $\left(\mathrm{kg} \mathrm{ha}^{-1}\right)$ applied in the Integrated farming system.

\begin{tabular}{|c|c|c|c|c|c|c|c|}
\hline Year & $\begin{array}{c}\text { Sowing } \\
\text { date }\end{array}$ & $\begin{array}{c}\text { Harvest } \\
\text { date }\end{array}$ & $\begin{array}{c}\text { Rainfall } \\
(\mathrm{mm})\end{array}$ & $\begin{array}{c}\text { Average } \\
\text { temperature } \\
\left({ }^{\circ} \mathrm{C}\right)\end{array}$ & $\begin{array}{c}\text { Nitrogen } \\
\left(\mathrm{kg} \mathrm{ha}^{-1}\right)\end{array}$ & $\begin{array}{c}\text { Phosphorus } \\
\left(\mathrm{kg} \mathrm{ha}^{-1}\right)\end{array}$ & $\begin{array}{c}\text { Potassium } \\
\left(\mathrm{kg} \mathrm{ha}^{-1}\right)\end{array}$ \\
\hline \hline 1999 & $23 / 10 / 98$ & $20 / 07 / 99$ & 435 & 8.1 & 23.8 & 15.0 & 31.6 \\
\hline 2000 & $28 / 09 / 99$ & $3 / 07 / 00$ & 301 & 9.5 & 25.3 & 5.0 & 18.3 \\
\hline 2001 & $29 / 09 / 00$ & $20 / 07 / 01$ & 408 & 10.4 & 29.0 & 5.8 & 23.3 \\
\hline 2002 & $4 / 10 / 01$ & $6 / 07 / 02$ & 310 & 9.0 & 44.2 & 15.8 & 16.6 \\
\hline 2003 & $9 / 10 / 02$ & $30 / 06 / 03$ & 264 & 7.7 & 34.2 & 21.6 & 26.6 \\
\hline 2004 & $2 / 10 / 03$ & $21 / 07 / 04$ & 450 & 8.2 & 39.8 & 19.1 & 16.6 \\
\hline 2005 & $1 / 10 / 04$ & $19 / 07 / 05$ & 398 & 8.2 & 49.2 & 22.5 & 10.0 \\
\hline 2006 & $7 / 10 / 05$ & $20 / 07 / 06$ & 522 & 7.9 & 58.3 & 22.5 & 0.0 \\
\hline 2007 & $2 / 10 / 06$ & $2 / 07 / 07$ & 347 & 10.0 & 58.0 & 28.3 & 56.6 \\
\hline 2008 & $9 / 10 / 07$ & $28 / 07 / 08$ & 467 & 8.9 & 57.5 & 28.3 & 21.6 \\
\hline
\end{tabular}

\section{Results and discussion}

Effect of farming system on yield parameters

The effects of years and farming systems on winter wheat yield parameters were significantly different $(\mathrm{P}<0.001)$, with the year $\times$ system interaction also being significant $(P \leq 0.041)$. In general, $\mathrm{KC}$ and grain yield were lower in the ECO system by about $25 \%$ (range: $12-31 \%$ ), except in drier years $(2000,2002,2003)$ when the differences were not significant. The variation in TGW between systems was less influenced by rainfall, and TGW was greater in the INT system in only three of the ten years compared. The lack of differences in drier years may be related to increased nutrient cycling (Cookson et al., 2006), water-holding capacity (Lotter et al., 2003),higher soil organic matter content, soil fertility (Macák et al.,2008,2009) in ecological systems, or the inability of wheat to use the extra fertiliser in the INT system. 
Table 2. Yield parameters for winter wheat grown in ecological (ECO) and integrated (INT) farming systems. Means and standard errors shown.

\begin{tabular}{|c|c|c|c|c|c|c|c|c|c|c|}
\hline & 1999 & 2000 & 2001 & 2002 & 2003 & 2004 & 2005 & 2006 & 2007 & 2008 \\
\hline \multicolumn{11}{|c|}{ Kernel count $\mathrm{x} 1000$ per $\mathrm{m}^{-2}$} \\
\hline $\begin{array}{c}\text { EC } \\
O\end{array}$ & $\begin{array}{r}13,5 \\
\pm 1.1\end{array}$ & $\begin{array}{r}13,4 \\
\pm 0.2\end{array}$ & $\begin{array}{r}11,9 \\
\pm 0.7\end{array}$ & $\begin{array}{l}11,3 \\
\pm 1\end{array}$ & $\begin{array}{r}15,2 \\
\pm 0.5\end{array}$ & $\begin{array}{r}12,4 \\
\pm 1.7\end{array}$ & $\begin{array}{r}13,0 \\
\pm 1.4\end{array}$ & $\begin{array}{r}17,2 \\
\pm 1.3\end{array}$ & $\begin{array}{r}13,6 \\
\pm 1.4\end{array}$ & $\begin{array}{r}12,3 \\
\pm 1.5 \\
\end{array}$ \\
\hline INT & $\begin{array}{r}16,4 \\
\pm 0.7 \\
\end{array}$ & $\begin{array}{r}14,2 \\
\pm 0.4 \\
\end{array}$ & $\begin{array}{r}15,9 \\
\pm 1.2 \\
\end{array}$ & $\begin{array}{r}10,6 \\
\pm 0.5 \\
\end{array}$ & $\begin{array}{r}14,9 \\
\pm 0.6\end{array}$ & $\begin{array}{r}16,1 \\
\pm 0.7 \\
\end{array}$ & $\begin{array}{r}17,0 \\
\pm 0.3 \\
\end{array}$ & $\begin{array}{r}22,3 \\
\pm 1.9 \\
\end{array}$ & $\begin{array}{r}13,2 \\
\pm 1.0 \\
\end{array}$ & $\begin{array}{r}12,1 \\
\pm 0.3 \\
\end{array}$ \\
\hline \multicolumn{11}{|c|}{ 1,000-grain weight $(\mathrm{g})$} \\
\hline $\begin{array}{c}\text { EC } \\
O\end{array}$ & $\begin{array}{r}45,9 \\
\pm 0.3\end{array}$ & $\begin{array}{r}40,1 \\
\pm 0.2\end{array}$ & $\begin{array}{r}42,7 \\
\pm 1.2\end{array}$ & $\begin{array}{l}48,6 \\
\pm 2.6\end{array}$ & $\begin{array}{r}30,2 \\
\pm 0.5\end{array}$ & $\begin{array}{r}42,5 \\
\pm 0.9\end{array}$ & $\begin{array}{r}37,9 \\
\pm 0.9\end{array}$ & $\begin{array}{r}39,6 \\
\pm 1.2\end{array}$ & $\begin{array}{r}38,5 \\
\pm 1.0\end{array}$ & $\begin{array}{r}41,3 \\
\pm 0.9\end{array}$ \\
\hline INT & $\begin{array}{r}50,5 \\
\pm 0.2\end{array}$ & $\begin{array}{r}39,9 \\
\pm 1.2\end{array}$ & $\begin{array}{r}40,7 \\
\pm 0.6\end{array}$ & $\begin{array}{r}53,2 \\
\pm 1.8\end{array}$ & $\begin{array}{r}33,5 \\
\pm 0.7\end{array}$ & $\begin{array}{r}47,7 \\
\pm 0.5\end{array}$ & $\begin{array}{r}38,6 \\
\pm 0.5\end{array}$ & $\begin{array}{r}39,9 \\
\pm 0.4\end{array}$ & $\begin{array}{r}35,5 \\
\pm 0.6\end{array}$ & $\begin{array}{r}42,1 \\
\pm 0.7\end{array}$ \\
\hline \multicolumn{11}{|c|}{ Grain yield (tonnes ha ${ }^{-1}$ ) } \\
\hline $\begin{array}{c}\mathrm{EC} \\
\mathrm{O}\end{array}$ & $\begin{array}{c}6.2 \\
\pm 0.54\end{array}$ & $\begin{array}{c}5.4 \\
\pm 0.06\end{array}$ & $\begin{array}{c}5.1 \\
\pm 0.32\end{array}$ & $\begin{array}{c}5.4 \\
\pm 0.35\end{array}$ & $\begin{array}{c}4.6 \\
\pm 0.09\end{array}$ & $\begin{array}{c}5.3 \\
\pm 0.8\end{array}$ & $\begin{array}{c}4.9 \\
\pm 0.55\end{array}$ & $\begin{array}{c}6.8 \\
\pm 0.37\end{array}$ & $\begin{array}{c}5,2 \\
\pm 1.4\end{array}$ & $\begin{array}{c}5,1 \\
\pm 1.4\end{array}$ \\
\hline INT & $\begin{array}{c}8.3 \\
\pm 0.35\end{array}$ & $\begin{array}{c}5.7 \\
\pm 0.29\end{array}$ & $\begin{array}{c}6.5 \\
\pm 0.44\end{array}$ & $\begin{array}{c}5.7 \\
\pm 0.45\end{array}$ & $\begin{array}{c}5.0 \\
\pm 0.32\end{array}$ & $\begin{array}{c}7.7 \\
\pm 0.42\end{array}$ & $\begin{array}{c}6.6 \\
\pm 0.13\end{array}$ & $\begin{array}{c}8.9 \\
\pm 0.7\end{array}$ & $\begin{array}{c}4.7 \\
\pm 0.23\end{array}$ & $\begin{array}{c}5.1 \\
\pm \\
0.16\end{array}$ \\
\hline
\end{tabular}

Yield efficiency

Although the yield parameters were usually lower for ECO, this is likely to be due to the higher level of fertiliser inputs used in the INT system. The efficiency of the two farming systems was compared by relating yield parameters to fertiliser inputs. The ECO systems was significantly higher per unit of nutrient added $(P<0.001)$ for all yield parameters (Table 3), This finding has important economic and environmental implications for farmers and land management authorities (Wood et al., 2006; Zingore et al., 2007), where resources such as water and energy-reliant fertilisers need to be used efficiently with regard to cost and off-farm impacts.

Table 3. Efficiency of fertiliser inputs on winter wheat yield parameters. Means and standard errors shown.

\begin{tabular}{|c|c|c|c|c|c|c|}
\hline \multirow{2}{*}{$\begin{array}{l}\text { Yield } \\
\text { parameters }\end{array}$} & \multicolumn{2}{|c|}{ Nitrogen $\left(\mathrm{kg} \mathrm{ha}^{-1}\right)$} & \multicolumn{2}{|c|}{ Phosphorus $\left(\mathrm{kg} \mathrm{ha}^{-1}\right)$} & \multicolumn{2}{|c|}{ Potassium $\left(\mathrm{kg} \mathrm{ha}^{-1}\right)$} \\
\hline & ECO & INT & ECO & INT & ECO & INT \\
\hline $\begin{array}{l}\text { Kernels }(1,000 \\
\left.\text { kernels } \mathrm{m}^{-2}\right)\end{array}$ & $\begin{array}{l}418 \\
\pm 15\end{array}$ & $\begin{array}{l}213 \\
\pm 9\end{array}$ & $\begin{array}{l}2014 \\
\pm 69\end{array}$ & $\begin{array}{l}694 \\
\pm 50\end{array}$ & $\begin{array}{l}3858 \\
\pm 13\end{array}$ & $\begin{array}{l}294 \\
\pm 21\end{array}$ \\
\hline $\begin{array}{l}1,000 \text { grain } \\
\text { weight }(\mathrm{g})\end{array}$ & $\begin{array}{c}1.28 \\
\pm 0.031\end{array}$ & $\begin{array}{c}0.59 \\
\pm 0.024\end{array}$ & $\begin{aligned} & 6.11 \\
& \pm 0.150 \\
&\end{aligned}$ & $\begin{array}{c}1.93 \\
\pm 0.134\end{array}$ & $\begin{array}{c}1.18 \\
\pm 0.029\end{array}$ & $\begin{array}{c}0.79 \\
\pm 0.034\end{array}$ \\
\hline $\begin{array}{l}\text { Grain yield (kg } \\
\mathrm{ha}^{-1} \text { ) }\end{array}$ & $\begin{array}{c}168,8 \\
\pm 6\end{array}$ & $\begin{array}{c}89,9 \\
\pm 5\end{array}$ & $\begin{array}{c}806,4 \\
\pm 27\end{array}$ & $\begin{array}{c}292,0 \\
\pm 21\end{array}$ & $\begin{array}{c}155,7 \\
\pm 5\end{array}$ & $\begin{array}{c}123,1 \\
\pm 9\end{array}$ \\
\hline
\end{tabular}

\section{Conclusions}

The INT system had higher yields in most years, with the ECO system having $12-31 \%$ lower yields, as measured by kernel count, 1,000 grain weight (TGW) and grain yield. The greater productivity of the INT system was achieved with significantly lower nutrient efficiency than the ECO system and there was no difference in yield between farming systems during drier years. These results indicate that ecological systems have 
increased drought tolerance, probably due to improved nutrient cycling and waterholding capacity, and synthetic fertilizer inputs were less effective when rainfall was low. Soil fertility building methods in ecological systems can lead to more soil organic matter, better aggregate stability, biologically more active soils and reduced soil compaction. The ECO system was able to produce higher yields than integrated or conventional systems per unit of nutrient applied, with a significantly higher output/input ratio for nitrogen, phosphorus and potassium. In a context of increasing economic and environmental pressure to use agricultural inputs efficiently, these results show that ecological farming systems have the potential to achieve consistent, moderate yields with a significantly lower reliance on external inputs and under sub-optimal climatic conditions.

\section{Acknowledgements}

The research presented in this paper was supported by VEGA No.1/0457/08. The authors also thank the SAIA, National Scholarship programme, SR for a mobility scholarship.

\section{References}

Cookson, W.R. - Marschner, P. - Clark, I.M. - Milton, N. - Smirk, M.N. - Murphy, D.V. - Osman, M. Stockdale, E.A. - Hirsch, P.R.: 2006. The influence of season, agricultural management, and soil properties on gross nitrogen transformations and bacterial community structure. Australian Journal of Soil Research. 44: 4. 453-65.

Czapka, M.: 2005 a. Ekonomiczne aspekty bezpieczeństva ekologicznego.Środowisko i Rozwój,WSEiA,Bytom,11,28-38.

Czapka, M.: 2005 b. Ekonomiczna dostepność zywności jako jeden z warunków bezpieczeństwa zywnościowego.Problemy ekologii,WSEiA-GWSP, 3,130-133.

Kudsk, P. - Streibig, J.C.: 2003. Herbicides - a two-edged sword. Weed Research. 43: 2. 90-102.

Lotter, D.W. - Seidel, R. - Liebhardt, W.: 2003. The performance of organic and conventional cropping systems in an extreme climate year. American Journal of Alternative Agriculture. 18: 3. 146-154.

Macák,M.- Žák,Š.- Birkás,M.- Djalovic,I.- Slamka,P.: 2008. The influence of an ecological and low input system on yield and yield components of spring barley. Cereal research communications, Vol.36,suppl.,1343-1346.

Macák,M. - Žák,̌̌ . - Szombathová,N. - Candráková,E.: 2009. The proportion of weather conditions on agronomic traits variability of winter wheat in environmentally sound technologies. Cereal research communications, 37. 61-64.

OECD.: 2004. Agriculture and the Environment: Lessons Learned from a Decade of OECD Work. Organisation of Economic Cooperation and Development, Paris.

Willer, H. - Yussefi-Menzler, M. -Sorenson, N. (eds.): 2008. The World of Organic Agriculture. Statistics \& Emerging Trends 2008. IFOAM and FiBL, Bonn \& Frick.

Wood, R. - Lenzen, M. - Dey, C. - Lundie, S.: 2006. A comparative study of some environmental impacts of conventional and organic farming in Australia. Agricultural Systems. 89: 2-3. 324-348.

Zingore, S. - Murwira, H.K. - Delve, R.J. - Giller, K.E.: 2007. Soil type, management history and current resource allocation: Three dimensions regulating variability in crop productivity on African smallholder farms. Field Crops Research. 101: 3. 296-305. 


\title{
RESPONSE OF FIELD AGROSYSTEMS PRODUCTIVITY TO CHANGED CONDITIONS IN THE CZECH REPUBLIC AFTER 1989
}

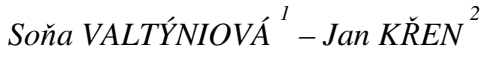 \\ ${ }^{1,2}$ Department of Agrosystems and Bioclimatology, Faculty of Agronomy, Mendel University in Brno, \\ Zemedelska 1, 63800 Brno, Czech republic, \\ 1 e-mail: sona.valtyniova@mendelu.cz \\ 2 e-mail: kren@mendelu.cz
}

\begin{abstract}
There was a great change in the state economic support and consequently in the inputs level (fertilizers and pesticides consumption) for agriculture after 1989 in the Czech Republic. In the same time, market conditions changed and therefore farmers changed the management (crop structure, omitting regular crop rotation etc.). These factors have caused the reduction of agrosystems homeostasis and increased their sensitivity to weather extremes. The paper investigates the changes in productivity of field crops as a measurable indicator of agrosystem performance and its sensitivity to external conditions. An example of main crops (wheat, barley, maize and oilseed rape) in the Czech Republic was used. The official data of the Czech Statistical Office and standard statistical methods were used for analyses. After about 9 years influence of new conditions (1992-2000), the inter-annual variability in crop yields started to increase. In wheat, barley and rape, increased yield variability in the period 2001-2008 compared to the previous periods was observed. In grain maize, the productivity trend change was different, influenced by intensification in this crop. Care of the agrosystems stability will be a challenge for the future.
\end{abstract}

Keywords: yield variability, agrosystem productivity

\section{Introduction}

Agroecosystem is an ecosystem dependent on human management. It is a very complex task for farmer to reach good yield and in the same time maintain quality of soil and ecological sources for the next years. The state of agroecosystem is affected by many factors. There was a significant change in the inputs level and some management practices in the Czech agriculture after 1989 (based on political regime change). Therefore agrosystem homeostasis has been disturbed. Clear trends in development of field production within long-term datasets since 1950 are observable (inputs level, crop structure, yield level etc.) but significant change in these trends occurred about 1990.

\section{Materials and methods}

As a measurable indicator of agrosystem homeostasis and resiliency, the variability (relative average deviation) in its productivity (yield given in cereal units per ha) was used. An example of main crops (wheat, barley, maize and oilseed rape) in the Czech Republic was assessed. Long-term yield data sets were divided into intervals of 19501963, 1964-1975, 1976-1991, 1992-2000 and 2001-2008 regarding changes in inputs level. The official statistic data (Czech Statistical Office, State Phytosanitary Administration, Central Institute for Supervising and Testing in Agriculture) and standard statistical methods were used for analyses. 


\section{Results and discussion}

Figure 1 shows development of the main intensification inputs: mineral fertilizers (given in NPK nutrients) and pesticides (given in active substance). Nutrients input had been increasing until maximum of $210 \mathrm{~kg} \mathrm{NPK} \mathrm{ha}^{-1}$ in 1986. Between the years 19901993 , it fell to the minimum of $72 \mathrm{~kg} \mathrm{NPK} \mathrm{ha}^{-1}$. This amount makes $36 \%$ of average in previous decade $(56 \%$ by $\mathrm{N})$. Nitrogen consumption started to increase after that, but phosphorus and potassium continued to decrease very slightly. Only after 2000, also the amounts of the consumed P and K started to increase, but slower than N. In 2008, NPK consumption was $99 \mathrm{~kg} \mathrm{ha}^{-1}$. Between 1990-1993, the drop in pesticides consumption also occurred. Maximum level was reached in 1985 when $2.42 \mathrm{~kg}$ of active substance $\mathrm{ha}^{-1}$ was used (Peterka et al. 2001). In 1993 it was only $0.85 \mathrm{~kg}$ of active substance ha ${ }^{-1}$. Since then, pesticide consumption grew very slightly, thanks to increasing use of growth regulators and stagnation in other categories of products in the same time.

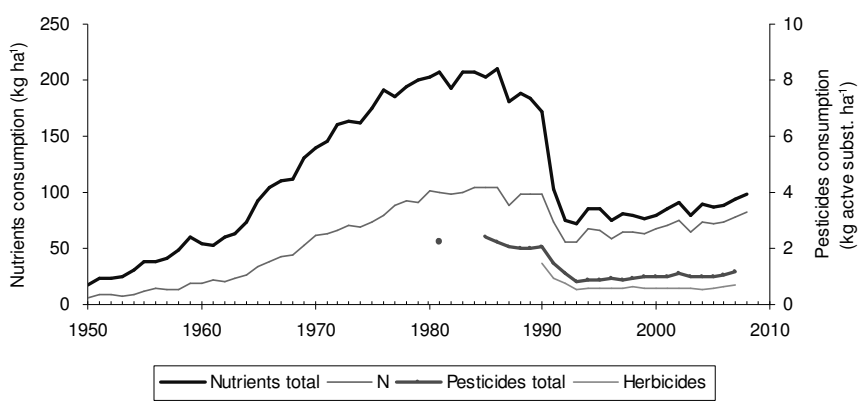

Figure 1. Development of fertilizer (nutrients: NPK $\mathrm{kg} \mathrm{ha}^{-1}$ ) and pesticides (active substance $\mathrm{kg} \mathrm{ha}^{-1}$ ) consumption in the period of 1950-2008

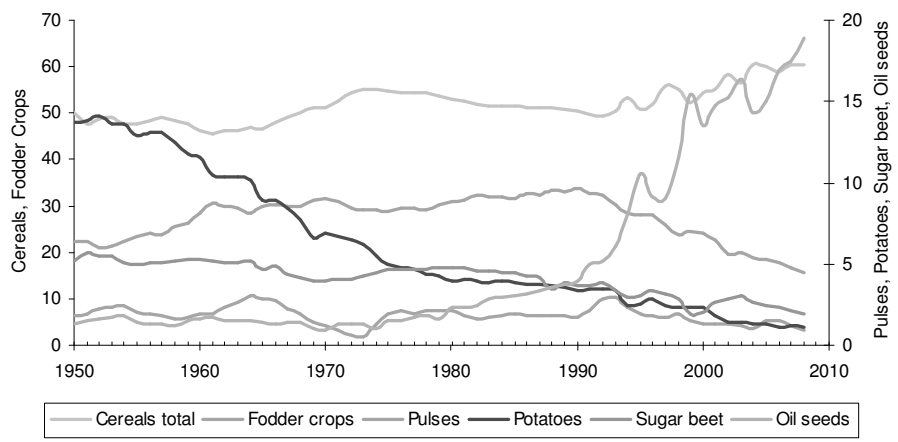

Figure 2. Development of the crop sturcture (\% of arable land area) in the period of 1950-2008

The changed market conditions and demands caused also changes in crop structure, and numbers and structure of animals, which influenced demand for fodder crops, straw 
management and use of farmyard manures. Figure 2 illustrates development in crop structure with significant changes in fodder crops, oil seeds and cereals starting in 1990. With regard to the rising intensity of field production (represented by inputs level), crop yields had been also increasing until the years 1986-1992. Than the yields decreased and after about 9 years of stagnation it started to be more fluctuant. The described development is clear in cereals (Figure 3), pulses and oilseed rape (Figure 3), but not so marked in potatoes, and to some extent can also be observed in sugar beet. Maize showed quite variable yields with slightly increasing trend and shift towards higher level about the year 1996 (Figure 3).
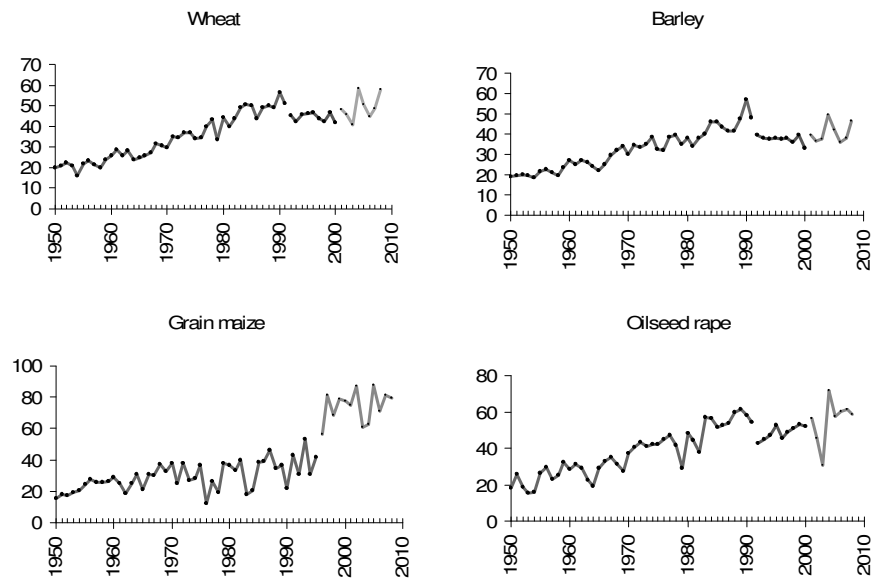

\footnotetext{
Figure 3. Development of the crop yields (cereal units ha ${ }^{-1}$ ) in the period of 1950-2008 and highlighted periods of changes in trend
}

Variability analyses of single crops productivity (Table 1) showed changes in trend corresponding with the changes in input level, but the situation was different in individual crops (Figure 3, Table 1). In the period before 1991, clear increasing trend in productivity was observable in cereal crops and oilseed rape. In grain maize, there was also increasing but slower tendency (Figure 3) and higher variability (Table 1). After 1992, when input level was declining dramatically, individual crops responded differently. Productivity of wheat and barley decreased compared to previous period with comparable variability in wheat and increased variability in barley in the same time (Table 2). The response of grain maize was totally different. The change in trend occurs between the years 1994-1997 when productivity level was significantly shifted to higher levels. Variability was higher than in previous period and also higher compared to other analyzed crops (Table 2). These results suggest higher affect of other factors (new hybrids, focusing on maize crop) in grain maize. In oilseed rape, the situation was similar to wheat and barley, but variability seems to be lower compared to these crops (Table 2). 
Table 1. Productivity of chosen crops (cereal units ha ${ }^{-1}$ ) and its variability (relative average deviation from trend in \%) within intervals corresponding to input level changes

\begin{tabular}{|c|c|c|c|c|c|c|c|c|}
\hline & \multicolumn{2}{|c|}{ Wheat } & \multicolumn{2}{|c|}{ Barley } & \multicolumn{2}{|c|}{ Grein maize } & \multicolumn{2}{|c|}{ Oilseed rape } \\
\hline & var. & prod. & var. & prod. & var. & prod. & var. & prod. \\
\hline $1950-1963$ & 1.14 & 22.76 & 1.32 & 22.14 & 8.77 & 22.72 & 21.73 & 24.32 \\
\hline 1964-1975 & 4.93 & 30.94 & 0.08 & 30.86 & 17.17 & 31.28 & 1.01 & 35.14 \\
\hline 1976-1991 & 5.85 & 45.45 & 6.21 & 41.64 & \multirow{2}{*}{12.19} & \multirow{2}{*}{32.96} & 0.44 & 49.91 \\
\hline $1992-1996$ & \multirow{2}{*}{5.66} & \multirow{2}{*}{44.38} & \multirow{2}{*}{8.78} & \multirow{2}{*}{37.45} & & & \multirow{2}{*}{2.36} & \multirow{2}{*}{48.72} \\
\hline $1997-2000$ & & & & & \multirow{2}{*}{18.26} & \multirow{2}{*}{74.59} & & \\
\hline $2001-2008$ & 9.11 & 49.33 & 9.35 & 40.75 & & & 5.69 & 55.33 \\
\hline
\end{tabular}

\section{Conclusions}

After about 9 years of influence of new conditions (1992-2000), the inter-annual variability in crop yields started to increase. In wheat and barley, increased yield variability in the period 2001-2008 was observed compared to the previous periods, which was in wheat $9.11 \%$ compared to $5.66 \%$ and in barley $9.35 \%$ compared to 8.78 $\%$. In oilseed rape was the development similar but variability in productivity was lower compared to wheat and barley. It was $5.69 \%$ in period $2001-2008$ and $2.36 \%$ in the previous one. In grain maize, the productivity trend change does not correspond with the average inputs level. Compared to other crops, higher intensification (new hybrids, higher inputs) occurred in grain maize. Improvement of the agrosystems resiliency will be a challenge. Therefore, production stability of the current agrosystems in the future is not certain.

\section{Acknowledgements}

The study was supported by Research plan MSM6245648905, financed by the Ministry of Education, Youth and Sports of the Czech Republic and project No. QH92242, financed by the Ministry of Agriculture of the Czech Republic.

\section{References}

Czech Statistical Office. Yearbooks and long-term data on official web: http://www.czso.cz

Peterka V. et al.: 2001. Praktická příručka pro zacházení s přípravky na ochanu rostlin. Státní rostlinolékařská správa. Agrospoj Praha 


\title{
SHORT TERM STUDY OF DAS-59122-7 MAIZE ON L1 AND L2 LARVAE OF SEVEN-SPOTTED LADYBIRD (COCCINELLA SEPTEMPUNCTATA) FEEDING ON THE BIRD CHERRY-OAT APHID (RHOPALOSIPHUM PADI)
}

Eszter TAKÁCS ${ }^{1,2}$ - Hajnalka BÁNÁTI ${ }^{1,3}$ - Adrien FÓNAGY ${ }^{l}$ - Béla DARVAS ${ }^{1}$

${ }^{1}$ Department of Ecotoxicology and Environmental Analysis, Plant Protection Institute, Hungarian Academy of Science, H-1022 Budapest, Herman Ottó út 15, Hungary. E-mail: teszter84@gmail.com

${ }^{2}$ Szent István University, PhD School of Environmental Sciences, H-2103 Gödöllő, Páter K. u. 1, Hungary

${ }^{3}$ Eötvös Loránd University, PhD School of Environmental Sciences, H-1518 Budapest, POB 32, Hungary

\begin{abstract}
Short term effects were studied on L1 and L2 larvae of $C$. septempunctata preying on $R$. padi living on DAS-59122-7 during maize pollination. Aphids were reared on the isoline and then transferred to maize, producing Cry34 + Cry35 toxins, for a duration of at least one week, where they were offered as prey in semifield tests. In the first series, one individual of $C$. septempunctata $(1 \mathrm{~L})$ was placed into the clip-isolator where the trial was conducted, which included four different combinations of food supply: aphids + maize pollen; only aphids; only maize pollen, no food, respectively. Aphid supply consisted of 10-15 aphid larvae and 2 aptera females. Isolators were placed on the rear surface of leaves at three levels, where pollen density (where applicable) was adjusted accordingly and provided by using wetted filter paper: bottom (200-300 pollen $\left./ \mathrm{cm}^{2}\right)$, ear level $\left(500-600\right.$ pollen/ $\left./ \mathrm{cm}^{2}\right)$ and under tassel $\left(800-1000\right.$ pollen $\left./ \mathrm{cm}^{2}\right)$, respectively. Evaluation on the $4^{\text {th }}$ day revealed that in the treatment where no pollen or aphid food source was offered all individuals died in L1 on both maize types tested. Where only maize pollen was provided, $10 \%$ molted to L2 without growth and then all individuals died. It can be concluded that no difference was detected between $C$. septempunctata L1 preying aphids feeding on isoline or DAS-59122-7 maize. In the second series, newly emerged $C$. septempunctata L2 were placed on the leaf surface into clip-isolator at three different leaf levels. Aphids were pretreated as described previously and then provided as food source. Results showed that the survival and development of L2 did not significantly differ on isoline and maize plants producing Cry3 toxins (Statistica program, $A N O V A+\mathrm{t}$-test).
\end{abstract}

Keywords: Coccinella septempunctata, early larval stages, Rhopalosiphum padi, Bt maize, DAS-59122, Cry3 toxin, semi-field study

\section{Introduction}

Cry toxins are naturally produced by the bacterium group Bacillus thuringiensis during sporulation (Ellis et al., 2002). Cry toxins are generally considered highly specific, however, side-effects on non-target insects have been reported as a result of exposure to Bt-plants (O'Callaghan et al., 2005). Zhang et al. (2006) found, based on non-validated ELISA, that the Cry1 toxin - expressed by Bt-cotton cultivars - can be transmitted via aphid prey (Aphis gossypii) to a higher trophic level and may alter biology of a predatory ladybird (Propylea japonica). The objective of our study was to investigate the impact of a Cry3 toxin producing event $D A S-59122-7$ on a non-target prey/predator system (Rhopalosiphum padi/Coccinella septempunctata) under semi- field conditions.

\section{Materials and methods}

Plant material and plantation

DAS-59122 and isogenic maize (PR36D79), provided by Pioneer Hi-Bred International Inc., were planted in 8 10x 10 m plots with 6 rows of isoline in Júlia-major, Hungary. 


\section{Insect sources}

Bird cherry-oat aphid ( $R$. padi) colonies were maintained on barley in greenhouse. Plants at 3-leaf stage (approximately $15 \mathrm{~cm}$ tall) were infested with $R$. padi, at which point they were transferred into larger boxes surrounded by a wood frame which was covered with fine mesh. To avoid host plant change type shock, at least 10 days prior to the experiments approximately 500 of $R$. padi were transferred on individual maize plants (DAS-59122 and its near isogenic line, these plants were isolated in a cage $2.5 \mathrm{~m}$ high and $0.5 \mathrm{~m}$ diameter).

Seven-spotted ladybird (C. septempunctata) adults were collected from an organic farm. They were maintained in greenhouse in box isolators and fed with $R$. padi. Eggs from C. septempunctata were removed from isolators and put in glass jars (at $20^{\circ} \mathrm{C}$ ). The emerged L1 or L2 were then used the subsequent in the experiments.

Studying effects of DAS-59122 maize on L1 instars of C. septempunctata

C. septempunctata L1 were placed individually into clip-isolator, in the trial which included four different combinations of food supply: aphids + maize pollen; only aphids; only maize pollen, no food, respectively. Fourteen entire maize plants (7 DAS59122 and 7 isogenic) were isolated under whole plant isolators, two were assigned to tassel-free conditions and the other five developed with tassel. In each whole plant isolator 21 leaf isolators were placed at three leaf levels (under the tassel, ear level, bottom level) on the underside of the leaf. Two $R$. padi aptera females were placed under each leaf isolator at one week prior to the test. Under no prey conditions, leaf isolators were installed only at the time of the placement of $C$. septempunctata. Pollen densities were adjusted accordingly with a fine brush onto a wet filter paper: $800-1000$ pollen/ $/ \mathrm{cm}^{2}$ modeling under tassel situation, 500-600 pollen/ $/ \mathrm{cm}^{2}$ at ear level and 200-300 pollen $/ \mathrm{cm}^{2}$ at the bottom leaf level. After four days the developmental stage and consumed $R$. padi were recorded.

Studying effects of DAS-59122 on L2 instars of C. septempunctata

Leaf isolators were placed randomly onto 21-21 plants in each plot at three levels as above. To aid assessment, leaf isolators were placed on the leaf surface. Two aptera $R$. padi were placed in each leaf isolator and after week the newly emerged L2 $C$. septempunctata larvae were also placed into the leaf isolator. Three days later leaf isolators together with maintaining leaves were removed and were investigated under binocular microscope. Total mortality percentage of $C$. septempunctata, at different leaves levels, developmental stadium and consumed $R$. padi were calculated. Data were analyzed with Statistica software. A one-way analysis of variance (ANOVA) and t-test was performed to detect any significant differences between treatments.

\section{Results and discussion}

Survival of L1 C. septempunctata 
Results showed that without pollen and aphid food source all individuals died in L1. When only pollen was provided did $10 \%$ of individuals molted and progress to $2^{\text {nd }}$ stage where all remaining individuals then died. It can therefore be concluded that pollen is insufficient food source for $C$. septempunctata larvae.

Detailed results of aphid + maize pollen and only aphid combinations of food are shown in Table 1. No difference was detected between $C$. septempunctata larvae feeding on isoline or DAS-59122-7 maize and both treatments of either aphid or aphid + maize pollen supply, under similar conditions.

Table 1. Effect on L1 of Coccinella septempunctata.

\begin{tabular}{|c|c|c|c|c|c|}
\hline Treatment & Leaf & Aphid & Pollen & $\begin{array}{c}\text { Development } \\
\text { stadium } \\
\end{array}$ & $\begin{array}{c}\text { No of aphids } \\
\text { consumed }\end{array}$ \\
\hline Cry3 & upper & R.padi & de-tassel & 2.00 & 10.83 \\
\hline Cry3 & ear level & R.padi & de-tassel & 2.00 & 12.33 \\
\hline Cry3 & lower & R.padi & de-tassel & 2.17 & 12.00 \\
\hline Cry3 & upper & R.padi & tassel & 2.00 & 12.00 \\
\hline Cry3 & ear level & R.padi & tassel & 2.00 & 11,17 \\
\hline Cry3 & lower & R.padi & tassel & 2.00 & 11,17 \\
\hline Isogenic & upper & R.padi & de-tassel & 2.00 & 10.83 \\
\hline Isogenic & ear level & R.padi & de-tassel & 2.00 & 10.50 \\
\hline Isogenic & lower & R.padi & de-tassel & 2.00 & 11.17 \\
\hline Isogenic & upper & R.padi & tassel & 2.17 & 15.17 \\
\hline Isogenic & ear level & R.padi & tassel & 2.33 & 15.33 \\
\hline Isogenic & lower & R.padi & tassel & 2.00 & 14.50 \\
\hline
\end{tabular}

Survival of L2 C. septempunctata

Results showed that survival and development of L2 C. septempunctata up till L3 did not significantly differ on different levels of leaves of isoline and Cry3 producing maize $(\mathrm{F}$ value $=0.91)($ Figure 1 . a). The data confirmed that Cry3 toxin producing maize via aphid prey (R. padi) do not alter with the survival of L2 C. septempunctata (Figure 1. b). Mortality was $6 \% \pm 4$ on isogenic and $10 \% \pm 4$ on DAS-59122 (F value $=0.51)$.

In this short term test, development of $C$. septempunctata L2 did not differ either feeding on DAS-59122 or it's near isoline cultivar ( $F$ value: 0.41). Futhermore, the development and the number of consumed $R$. padi during L2 stadium did not different in either the Cry3-maize or its isogenic line $(\mathrm{F}$ value $=0.65)$ (Figure 2. a and b.). 

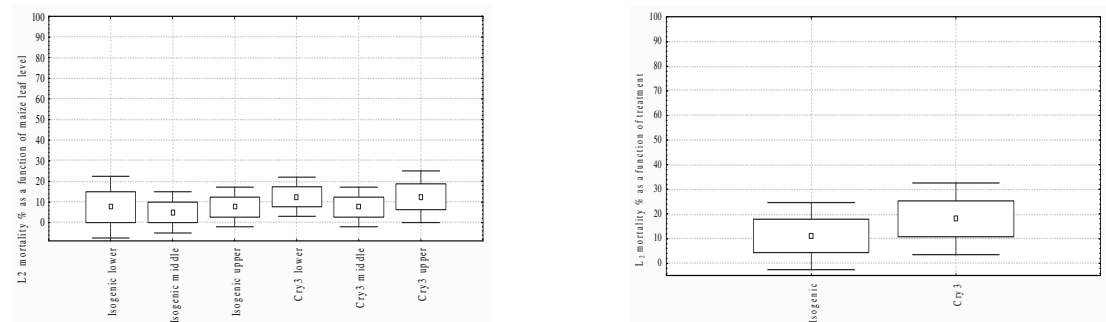

Figure 1. Mortality \% of L2 stadium C. septempunctata up till L3 at different leaf levels of isogenic and Cry3 maize (a) and total mortality on Cry3 and isogenic maize (b)
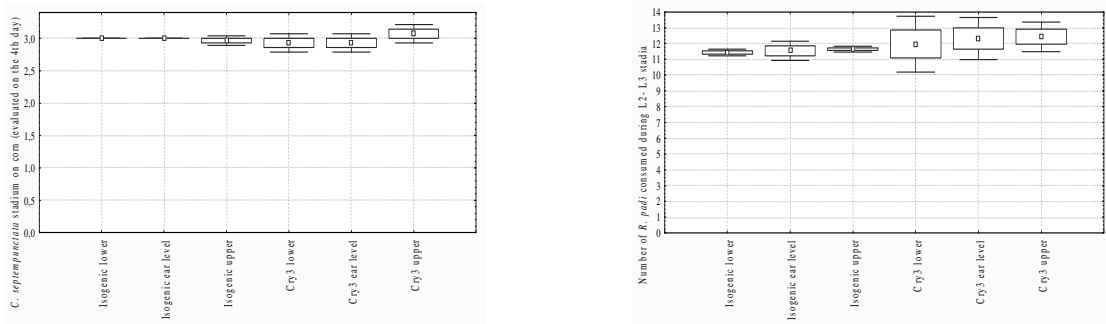

Figure 2. Developmental stadium of L2 C. septempunctata (a) and consumed R. padi (b) on the $4^{\text {th }}$ day

\section{Conclusions}

DAS-59122-7 maize expresses Cry34 and Cry35 toxins exhibiting insecticidal effects against coleopteran species, such as corn rootworm (Diabrotica spp.). Several aphid species (Rhopalosiphum maydis, R. padi, Aphis fabae etc.) live on maize in Hungary. Ladybird species are frequently found on aphid-infested plants. Seven-spotted ladybird (C. septempunctata) is one of the most common aphidophagous predators in Europe, both the larvae and adults are natural enemies of aphids. We investigated the acute, short term effects of DAS-59122-7. No side-effects were found during early larval stages of $C$. septempunctata. Further studies (effects on reproduction) are going on.

\section{Acknowledgements}

This work was sponsored by Pioneer Hi-Bred International, Inc. (Ankeny, IA, USA).

\section{References}

Ellis, R.T. - Stockhoff, B.A. - Stamp, L. - Schnepf, H.E. - Schwab, G.E. - Knuth, M. - Russell, J. Cardineau, G.A. - Narva, K.E.: 2002. Novel Bacillus thuringiensis binary insecticidal crystal proteins active on western corn rootworm, Diabrotica virgifera LeConte. Appl Environ Microbiol. 68: 1137-1145

O'Callaghan, M. - Glare, T.R. - Burguess, E.P.J. - Malone, L.A.: 2005. Effects of plants genetically modified for insect resistance on nontarget organisms. Annu. Rev. Entomol. 50: 271-292.

Zhang, G.F. - Wan, F.H. - Lövei, G.L. - Liu, W.X. - Guo, J.Y.: 2006. Transmission of Bt toxin to the predator Proplylaea japonica (Coleoptera: Coccinallidae) through its aphid prey feeding on transgenic $B t$ cotton. Environ. Entomol. 35: 143-150. 


\title{
SITE-SPECIFIC NUTRIENT REPLENISHMENT FOR WINTER WHEAT (TRITICUM AESTIVUM L.)
}

\author{
István BALLA ${ }^{1}$ - Mátyás CSIBA ${ }^{2}$ - Gergö Péter KOVÁCS ${ }^{1}$ - Márton JOLÁNKAI ${ }^{1}$ \\ Miklós NEMÉNYI ${ }^{2}$ \\ ${ }^{1}$ Department of Crop Production, Institute of Crop Production, Faculty of Agricultural and Environmental \\ Sciences, Szent István University, Páter Károly utca 1., Gödöllö, H-2100, Hungary, \\ e-mail: Balla.Istvan@mkk.szie.hu \\ ${ }^{2}$ Institute of Biosystems Engineering, Faculty of Agricultural and Food Sciences, University of West \\ Hungary, Vár 2., Mosonmagyaróvár, H-9200, Hungary, e-mail: nemenyim@mtk.nyme.hu
}

\begin{abstract}
Site-specific nutrient replenishment is one of the key solutions of precision agriculture. In this article authors compare two different situations, evaluating the resilience of an agro-ecosystem. Data have been collected in two different winter wheat cropyears (2004 and 2009). Prior to 2004 site-specific nutrient replenishment was applied to maize (2002) and spring barley (2003). In 2004 the experiment was still going on with winter wheat. Prior to 2009 spring barley (2007) and maize (2008) was cultivated on the same field, however during this period uniform nutrient replenishment was applied. According to the yield maps, collected by means of precision agriculture technology, in case of precision farming including site-specific nutrient replenishment were applied, soil and other field characteristics were not reflected in yield. Without applying site-specific nutrient replenishment, yield indicated the differences in soil and other field characteristics, which proves that the agro-ecosystem has been treated in a resilient way by applying precision agriculture in the investigated field.
\end{abstract}

Keywords: precision agriculture, site-specific nutrient replenishment, winter wheat, soil resilience

\section{Introduction}

Winter wheat provides a basic staple for mankind. This crop is one of the most important cereals in Hungary with a high economic value (Klupács et al., 2007).

In technology intensive farming, nutrient replenishment is mandatory for winter wheat, major share of this nutrient is fertilizer (Ragasits, 1998). Along with the emphasize of nutrient replenishment Koltay and Balla $(1975,1982)$ state that for the increase of yield of winter wheat in Hungary, the most important factor was the adaptation of the well chosen amount and share of fertilizers according to the given soil parameters.

Effects of different fertilizers on different plants are reported by several authors (Balla Kovács et al., 2008; Vágó et al., 2008; Sipos et al., 2008). Various authors - especially from the international literature - are suggesting very different amount of fertilizer as well as different fertilizing time depending on the soil and ecological situation of the field they are working on. A long term experiment is published by Pepó (2004) about the fertilizer supply of winter wheat in Hungary.

Precision agriculture technology in field circumstances proved that conventional nutrient replenishment practices are not necessarily applicable for sustainable agriculture (Milics et al., 2008; Neményi and Milics, 2008).

For determination of sufficient amount of fertilizers, instead of direct measurement, data collection by means of indirect indicator measurements is more reliable in order to apply variable rate application (Schnug et al., 1997). One of these indicators can be the soil parameters (Németh et al., 2007). Soil parameters can be mapped by GIS methods to ensure visualization of within field differences (Morschhauser and Milics, 2009; Milics et al., 2006). 


\section{Materials and methods}

Soil quality differences may occur within a small field even. For achieving a relatively high yield on the whole field it is necessary to know the special demand of the different locations. By applying precision (site-specific) technology during harvest, yield and quality parameters can be measured and later mapped, therefore heterogeneity of such parameters can be visualized and the maps can be used later as a decision support for the farmers. Yield map is created according to the data measured during harvest. For spatial data collection, location is mandatory to know, therefore positioning is applied for each measurement. During harvest it is advised that the accuracy of the Global Positioning System (GPS) should be submeter or even better.

Harvest in this experiment was carried out by a Deutz-Fahr harvester, equipped with a Trimble dGPS receiver and Agrocom yield monitoring system. According to the data collected in both years, yield map was created by ArcView GIS software.

For soil parameter collection different philosophies can be applied. Either the field is divided into smaller treatment units, or according to other data available (yield, electrical conductivity, etc.) soil sampling points are decided. Soil parameters after sampling have to be analyzed in an accredited laboratory. Soil samples were collected in 2001, 2005 and 2009 in the depth of $25 \mathrm{~cm}$. Each treatment unit was roughly $50 \mathrm{~m}$ by $50 \mathrm{~m}$, and 15-20 samples were collected and averaged from one unit.

According to the data collected by yield measurement and soil analysis, nutrient replenishment plan has to be made. With the available technology, variable rate application of the different fertilizers can be carried out. The aim in this case is the collection of the information about the fertility of the soil, the increase of fertility where it is needed and the preservation of the fertility on the whole field.

The experimental research field is located near Mosonmagyaróvár, Györ-Moson-Sopron County, Hungary. The experimental field is 23.52 hectare.

In this paper two experimental year's (2004 and 2009) research results are reported out of the ongoing long term precision agriculture research project. In both years winter wheat (Triticum aestivum L., Lupus cultivar) was produced, which is known for its reliable productivity and stable quality.

In year 2004 forecrop of winter wheat was maize (2002) and spring barley (2003). In these years nutrient replenishment was carried out by variable rate technology. Following the harvest of spring barley (2003) an average $147 \mathrm{~kg} / \mathrm{ha}$ nitrogen was replenished in the form of $34 \%$ ammonium nitrate in two different time as base and head fertilizer. Phosphate (23 kg/ha on average) was replenished in the form of superphosphate, and potassium ( $87 \mathrm{~kg} / \mathrm{ha}$ on average) was applied in form of $60 \%$ potassium chloride. According to the yield and soil maps, nutrient replenishment plan was created by the Proplanta model (ProPlanta Bt 2006). Variable rate applications of the fertilizers were carried out by an Amazone Za-M type fertilizer spreader.

In 2009 nitrogen $(400 \mathrm{~kg} / \mathrm{ha})$ was replenished in the form of ammonium nitrate $(34 \% \mathrm{~N})$ at autumn and in spring in 50:50 percent. In this year potassium and phosphorus was not replenished. Forecrops were spring barley (2007) and maize (2008). Replenishment in this year was identical. 


\section{Results and discussion}

On the investigated field site-specific crop production has been applied since 2001. Yield mapping is carried out in every year, however variable rate nutrient replenishment was carried out only between 2002 and 2006. It can be clearly seen from Figure 1 that due to large amount of complex fertilizer and variable rate application, yield in 2004 was nearly homogenic and close to the possible maximum. (The yield maps of the earlier years predicted this homogenic map.)

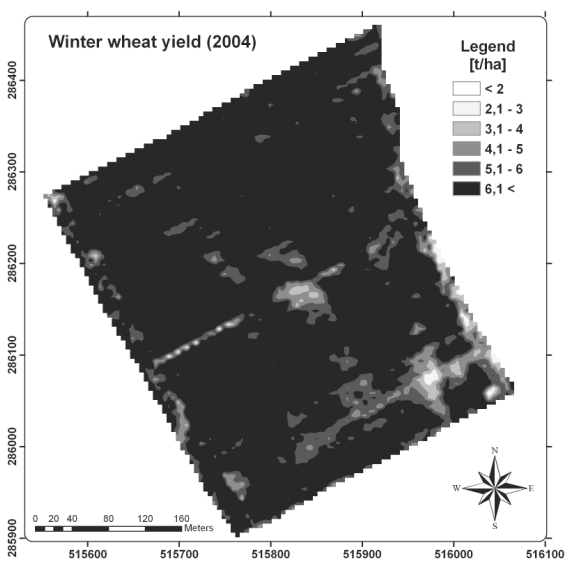

Figure 1. Winter wheat yield (2004)

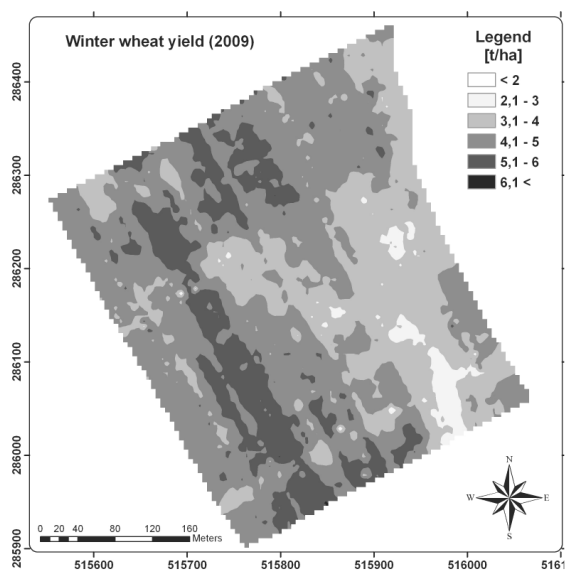

Figure 2. Winter wheat yield (2009)

In Figure 2 yield map visualizes heterogenic appearance. The differences in soil parameters as well as in micro relief in absence of site-specific nutrient replenishment are clearly visible on the yield map. It can be stated therefore that in case of continuous site-specific nutrient replenishment differences in soil parameters and micro relief are effaced concerning yield differences, however discontinuing variable rate application will express the same heterogeneity of the field. It can be also stated that efficiency of fertilizer uptake was increased by variable rate application, as compared to the conventional nutrient replenishment technology; the amount of applied fertilizer is 10$20 \%$ less. On the other hand application of precision agriculture technology, production of a given field is increasing as yield is higher and nearly homogeneous in this case.

\section{Conclusions}

It can be stated that - according to the investigations - yield within a heterogenic field can be homogenized in a higher level due to site-specific management. By applying precision agriculture management technology yield differences depending on soil properties can be minimazed, at the same time turning back to the conventional nutrient replenishment these differences will appear again. We can also state that by applying site-specific nutrient replenishment efficiency and profitability can be increased. This technology should be widely used in the farming practise as it is environmental friendly, 
produces higher quality raw materials, protects soil as well as decreases the input and results higher efficiency. Precision agriculture technology therefore is a possible strategy for plant producers as it counts with the aspects of profitability as well as environmental issues.

\section{Acknowledgements}

This project was supported by the University of West Hungary - Institute of Biosystems Engineering and Szent István University - Institute of Crop Production.

\section{References}

Balla Kovács, A. - Sipos, M. - Kremper, R.: 2008. Influence of bio- and chemical fertilization on nitrate accumulation, phosphorus and calcium content in lettuce (Lactuca sativa L.). Cereal Research Communications. 36. 555-558. VII. Alps-Adria Scientific Workshop. Stara Lesna.

Klupács, H. - Nyárai H., F. - Balla, I. - Jolánkai, M.: 2007. Water availability-a stressor influencing quantity and quality of winter wheat (Triticum aestivum L.) yield. Cereal Research Communications, 37: Suppl. 361-364.

Koltay, Á. - Balla, L.: 1975. Búzatermesztés és nemesítés. Mezőgazda Kiadó, Bp. 22-29.

Koltay, Á. - Balla, L.: 1982. Búzatermesztés és nemesítés. Mezőgazda Kiadó, Bp. 51-82.

Milics, G. - Nagy, V. - Stekauerová, V.: 2006. Application of GIS for evaluating, monitoring and presenting groundwater and soil moisture data. Pollution and Water Resources Columbia University Seminar Proceedings, Vol. XXXVI, New York, USA. 69-75.

Milics, G. - Smuk, N. - Nagy, V.: 2008. Precíziós gazdálkodás - a megújuló biológiai eredetủ alapanyagok előállítása környezetkímélő módon. MTA RKK, Pécs. 138-146.

Morschhauser, T. - Milics, G.: 2009. Mapping stress in natural and artificial ecosystems. Cereal Research Communications, 37: Suppl., 577-580.

Neményi, M. - Milics, G.: 2008. Application of Precision Agriculture in Environmental protection. (in Hungarian: A precíziós mezőgazdaság környezetvédelmi alkalmazása) In.: Tamás J. (szerk.): Agrárium és környezetgazdálkodás. Mezőgazda Kiadó, Budapest, 272-279.

Németh, T. - Neményi, M. - Harnos, Zs.: 2007. A precíziós mezőgazdaság módszertana. JATE Press - MTA TAKI. Szeged. 229

ProPlanta Bt.: 2006. Economic and environmentally sound plant nutrition advisory system (in Hungarian: MTA TAKI - MTA MgKI Költség- és környezetkímélő tápanyagellátási szaktanácsadási rendszer). www.proplanta.hu

Pepó, P.: 2004. Fertilizer supply of winter wheat in Hajduság. (in Hungarian: Öszi búza tápanyag ellátottsága a Hajdúságban. MTA DSc. thesis.)

Ragasits, I.: 1998. Búzatermesztés, Mezőgazda Kiadó, Budapest, 61

Schnug, E. - Panten, K. - Haneklaus, S.: 1998. Sampling and Nutrient Recommendations - the Future. Communications in Soil Sciense and Plant Analysis, 29 (11-14), 1455-1462.

Sipos, M. - Balla Kovács, A. - Oláh Zsuposné, Á.: 2008. Effect of nitrogen-supply, nickel-contamination and liming on the chemical composition of perennial ryegrass (Lolium perenne L.). Cereal Research Communications. 36. 447-450. VII. Alps-Adria Scientific Workshop. Stara Lesna.

Vágó, I. - Kátai, J. - Sipos, M. - Balla Kovács, A. - Kincses, I.: 2008. Changes of yield amount and some content parameters of strawberry (Fragaria ananassa) as affected by potassium and magnesium fertilization. International Symposium "Risk Factors for Environment and Food Safety" Oradea, Romania. 317-322. 


\title{
THE POSSIBLE CIRCUMSTANCES OF THE POST 2013 CAP BY AGRO-ECOSYSTEMS
}

Miklós VÁSÁRY-Róbert BUZÁS

Szent István University, 2100 Gödöllő, Páter Károly utca 1.

\begin{abstract}
Absctract: 2013 will be an important year for European agriculture. The compromise in 2003, to freeze the level of agricultural spending, will come to end and the same time a new financial perspective will be implemented. This time could be the start of a new era for the Common Agricultural Policy (CAP) still governed by principles created in 1957. The CAP condition will depend on the coming European discussions about the future of the budget which will include a discussion on EU's challenges and political priorities. The last CAP reforms and the debate on "health check" were unable to create an efficient, sustainable, and for all member states acceptable policy. The debate on CAP 2013+ is already started; many of the interest (member states, tax payers, NGO-s etc.) are trying to influence the concrete conditions. By the next CAP there will be three points in the centre of interest: the recent financial crisis, the climate change and the controversy regarding public goods and externalities. In this paper we will analyse these main factors and possible consequences.
\end{abstract}

Keywords: Common Agricultural Policy, public goods, agricultural restructuring

\section{Introduction}

Today's EU Common Agricultural Policy CAP has been transformed into a multifunctional policy, supporting market oriented agricultural production throughout Europe, while also contributing to living rural areas, and environmentally sustainable production.On 20 November 2008 the EU agriculture ministers reached a political agreement on the "Health Check" (HC) of the CAP. The actions of HC should modernise, simplify and streamline the CAP and remove restrictions on farmers, thus helping them to respond better to signals from the market and to face new challenges. There are two main groups of measures: (1) changing the productions mechanism (milkquotas, intervention, etc); (2) changing some elements of the support system, (Decoupling, expending single area payments, shifting money to Rural Development etc.). (Halmai, 2006) The debate on the future shape of the common agricultural policy is gaining momentum as we move towards the end of 2013 and new overall EU budget allocations are fixed for the various policies for 2014 and beyond.A review is currently taking place of all aspects of the EU budget and the funding of the various policies post 2013. The debate on the CAP post 2013 will mainly focus on the need to have a strong EU policy for agriculture and rural development which will: (1)address concerns about food security while the world's population is rapidly increasing; (2)ensure good land management, save and improve the biodiversity, the level of agroecosystems; while, $80 \%$ of EU territory is covered by farming and forestry (3)to help tackle the problem of climate change: because arming will have to cut its emissions as well as adapt to the effects of climate change; (4)support balanced development in our rural areas where more than half the EU's population live. It will be important that (a) the CAP leaves room for farmers to be as market-oriented as possible; (b) the CAP gives farmers some kind of safety net so that occasional crises do not inflict serious long-term damage on our production base; (c) the CAP helps farming to modernise, to provide public goods (such as maintaining attractive cultivated landscapes, contributing to the cultural 
heritage of regions or enhancing the environment) and to meet various new challenges such as climate change.

\section{Material and methods}

On the basis of the Commissions latest outlook for agricultural commodities in the EU27 over the 2008-2015 period can be elaborated on the basis of specific assumptions on agricultural and trade policies, and the macro-economic environment. The macroeconomic environment is projected to be shaped over the short term by the consequences of the financial and economic crisis, which is expected to put severe pressure on the real economy. The world economy has entered into the deepest crisis for more than 60 years. The economic growth in the EU is estimated to fall from $1.0 \%$ in 2008 to $-1.8 \%$ in 2009 , with a modest recovery of $0.5 \%$ in 2010 . At global level, world GDP is projected to decline by $0.5 \%$ in 2009 but rebound by $2.6 \%$ in 2010 . The medium-term perspectives for the EU economy would exhibit a slow and modest recovery. The breadth and depth of the crisis are still difficult to assess, and the economic outlook remains subject to important uncertainties with significant (mainly downside) risks that could significantly alter commodity market projections. While the agricultural sector is generally more resilient to economic crises than other sectors, it is expected to face great challenges, especially in demand growth and farm income, which may continue to exert strong pressure on agricultural prices and trigger significant structural adjustment. Whereas food demand will be directly negatively affected in the higher value-added sectors (especially in the livestock and dairy sectors), the economic crisis should also be felt indirectly in other parts of the agricultural economy: in the arable crop sector through feed demand, in the energy crop sector, as well as in the upstream and downstream industries. Over the short term limited growth in cereal, oliseed demand is foreseen, decline in meat and milk sector, but in the medium term displaying a gradual (in different path) growth. Despite the significant short-term setback in the wake of the economic recession, the medium-term prospects for EU agricultural income remain positive with the aggregate income in real terms and per labour unit exceeding the very favourable 2007 year by $7.5 \%$ in 2015. (EC, 2009a)

The present financial and economical problems are focusing the attention on the coming external problems of agricultural. The direct payments and the financial resources of the rural development have directed effect on the environment, on the ecosystems. Along the payments there are two main problem groups: (1) the public goods and services and (2) the climate change. These problems have enormous effect on the post $2013 \mathrm{CAP}$ and on the consequences. (EC, 2009a)(EC, 2009b)

In certain respects, agriculture is like other economic sectors, with a large number of producers participating in a range of markets for food, fibre, and raw materials for energy and industrial products. In other respects, it has specific characteristics which mean that the potential for the provision of public goods in the field of the environment is particularly prevalent in this sector. It is widely argued that securing the provision of public goods provides a valid reason for public intervention in a market economy. The public goods concept is well established in economic theory which defines public goods by the following characteristics: (a) non-excludable - if the good is available to one person, others cannot be excluded from the benefits it confers; (b) non-rival - if the 
good is consumed by one person it does not reduce the amount available to others. In reality, these characteristics of non-excludability and non-rivalry may be exhibited to almost any degree, and indeed pure public goods are rare. This is because the potential sometimes exists to exclude people who do not contribute to covering the costs associated with the provision of a particular public good, and certain public goods, such as popular cultural landscapes, can become congested, leading to a loss of enjoyment. Given the defining characteristics of public goods, their supply cannot be secured through markets. This is because non-excludability and non-rivalry in consumption imply that users have no incentive to pay for public goods, often leading to overexploitation. On the supply side, farmers have little incentive to provide public goods because they are not being paid to do so. Public intervention is not always needed to secure the supply of public goods provided by agriculture. Certain quantities of public goods may be provided incidentally, as a side-effect of economically viable activities, or as a result of farmer altruism or self-interest. To achieve a desirable level of public goods, policy actions are needed, unless demand is satisfied by incidental delivery. Farmers need to be incentives to pursue certain farming practices in order to maintain landscape features, restore and maintain specific habitats, or to manage natural resources such as water and soils, for example. So society has to purchase what amounts to a reallocation of resources to underpin the provision of public goods. In this point can be make a real and useful connection between direct payments and public goods in the post 2013 period, to achieve a sustainable CAP. (Cooper, 2009) Agriculture is particularly vulnerable to the impacts of climate change. The most significant effects on EU agriculture will be manifest through the increasing frequency and severity of extreme weather events and through changes in the availability of water. Climate change will have the most severe impact in regions that are already under pressure and at risk of marginalization. Climatic changes are likely to increase both the volatility of markets, by changing production patterns, and the economic disparities between rural areas. On the positive side agriculture can play a role in the mitigation of climate change by reducing dependency on fossil fuels and diversifying supplies and as a carbon sink.

\section{Results and discussions}

The overall outlook for EU agricultural markets remains subject to some important uncertainties, most of which on the downside. They concern in particular the extent of the ongoing financial and economic crisis with its impacts on exchange rates, disposable income, labour market, asset values, access to credit and energy prices. Other factors such as future changes in agricultural and trade policies as well as the outcome of the current international trade negotiations, the policies on renewable energy, the path of technological change and future climatic conditions could also have far reaching implications for the future pattern of EU agricultural markets.

The evidence of undersupply is further substantiated by estimates of the monetary value of environmental goods and services and the cost of policy inaction. The society is underestimating the scale of environmental degradation coherent with the effects of climate change and that the cost of action to improve environmental delivery may be considerably less than the cost of inaction. So it is need to provide an important stimulus to strengthen the actions and budgetary resources necessary to enhance the

635 DOI: 10.1556/Novenyterm.59.2010.Suppl.6 
delivery of environmental public goods. Many of these public goods have a strong cross border element or are matters of EU common interest. As a result, securing their provision is an appropriate subject of EU policy. Financial solidarity in bearing the costs of providing public goods adheres to the principles of cohesion. By the provision of public goods have the administrative programs (Leader+, Natura 2000) important role, but other CAP measures, such as the decoupled direct payments which make a substantial contribution to farm incomes. Some of farms in receipt of these payments deliver public goods and certain of these may rely on these payments to maintain their economic viability, thereby enabling them to continue to provide public goods some other farms in receipt of these payments, however, may not be providing public goods or may even be causing environmental degradation. It can be identified if we look ahead towards a revision of the CAP in which the focus on the provision of environmental public goods is strengthened. These are: giving more emphasis to the integration of environmental objectives, establishing appropriate targets, enhancing the effectiveness and efficiency, improving implementation, securing sufficient budgetary resources.

\section{Conclusions}

The ongoing financial and economic crisis and the consequences of these will heavily influence the CAP in the post 2013 period. In looking ahead over the next decade or more, changes in agricultural land use and management will alter the pattern of provision of public goods. The drivers of agricultural restructuring point to a diminution in the practices needed to provide these goods but there are also examples of trends in the other direction, such as increases in the energy efficiency of farming operations. That said, it seems likely that the incidental provision of environmental public goods by farmers will decline and additional demands will be made on policy interventions to address undersupply. Policy intervention will be required across a large proportion of the farmed area, including the more intensive arable regions, to ensure the retention of soil functionality, the maintenance and improvement of water quality, reductions in greenhouse gas emissions, improved sequestration of carbon and enhanced resilience to flooding, as well as contributing to landscape and biodiversity goals. Alongside these interventions at the landscape scale, specific measures which are more precisely targeted in the locations where the supply of public goods is particularly concentrated, notably in the more extensively grazed areas, will also be critical.

\section{References}

AEA Energy \& Environment: 2007.Adaptation to Climate Change in the Agricultural Sector, Brussels

Cooper H. - Hart K. - Baldock D.: 2009. Provision of Public Goods through Agriculture in the European Union, Institute for European Environmental Policy: London

European Commission: 2007. Situation and prospects for EU agriculture and rural areas, Brussels

European Commission: 2009. a) "Prospects for agricultural markets and income in the European Union 20082015", Brussels,

European Commission: 2009. b)The role of European agriculture in climate change mitigation 2009/1093

Halmai, P: 2006. Integration of the Hungarian Agro-economy into the EU - Squeaky Adaptation, Long-term Structural Tensions, Development and Finance, 2006/2 pp.32-41.

Núñez Ferrer - J., Kaditi - A.E.: 2008. The EU added value of agricultural expenditure - from market to multifunctionality - gathering criticism and success stories of the CAP, CEPS 